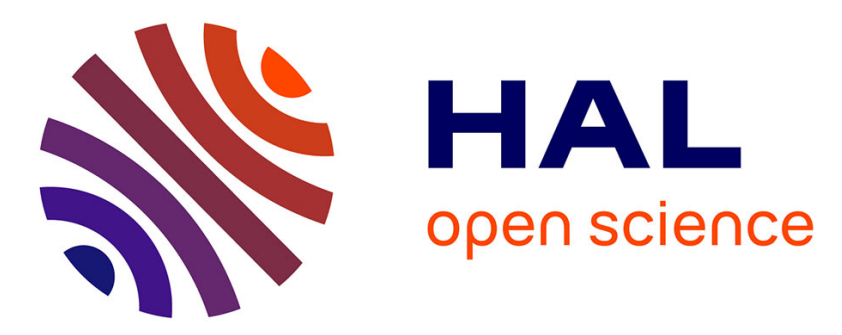

\title{
Multi-port power converter for segmented PEM fuel cell in transport application
}

\author{
A. de Bernardinis, E. Frappé, O. Béthoux, C. Marchand, G. Coquery
}

\section{To cite this version:}

A. de Bernardinis, E. Frappé, O. Béthoux, C. Marchand, G. Coquery. Multi-port power converter for segmented PEM fuel cell in transport application. European Physical Journal: Applied Physics, 2012, 58 (2), pp.20901. 10.1051/epjap/2012120056 . hal-01283668

\section{HAL Id: hal-01283668 https://hal.science/hal-01283668}

Submitted on 3 May 2019

HAL is a multi-disciplinary open access archive for the deposit and dissemination of scientific research documents, whether they are published or not. The documents may come from teaching and research institutions in France or abroad, or from public or private research centers.
L'archive ouverte pluridisciplinaire HAL, est destinée au dépôt et à la diffusion de documents scientifiques de niveau recherche, publiés ou non, émanant des établissements d'enseignement et de recherche français ou étrangers, des laboratoires publics ou privés. 


\section{Accepted Manuscript}

Multi-port Power Converter for Segmented PEM Fuel Cell in Transport Application. Simulation with fault tolerant strategy

A. De Bernardinis, E. Frappé, O. Béthoux, C. Marchand and G. Coquery

DOI:

10.1051/epjap/2012120056

Reference:

Publisher:

EDP Sciences

To appear in:

The European Physical Journal Applied Physics

Received date: $\quad 14$ February 2012

Accepted date: $\quad 3$ April 2012

Date of Publication: $\quad$ Available online 9 May 2012 (Volume 58, Number 2, May 2012)

Please cite this article as: A. De Bernardinis, E. Frappé, O. Béthoux, C. Marchand and G. Coquery, Multi-port Power Converter for Segmented PEM Fuel Cell in Transport Application. Simulation with fault tolerant strategy, The European Physical Journal Applied Physics, Volume 58, Issue 2, May 2012, Pages 1-15, DOI: 10.1051/epjap/2012120056.

\section{http://dx.doi.org/10.1051/epjap/2012120056}

Document Version: Early version, also known as pre-print

This is a PDF file of an unedited manuscript that has been accepted for publication. As a service to our customers we are providing this early version of the manuscript. The manuscript will undergo copyediting, typesetting, and review of the resulting proof before it is published in its final form. Please note that during the production process errors may be discovered which could affect the content, and all legal disclaimers that apply to the journal pertain. 


\title{
Multi-port Power Converter for Segmented PEM Fuel Cell in Transport Application. Simulation with fault tolerant strategy
}

\author{
Alexandre De Bernardinis ${ }^{1}$, Emmanuel Frappé ${ }^{1}$, Olivier Béthoux ${ }^{2}$, Claude Marchand ${ }^{2}$, and \\ Gérard Coquery ${ }^{1}$
}

\author{
${ }^{1}$ IFSTTAR LTN / SPEE Labs, 25, allée des Marronniers - Satory, FR- 78000 Versailles, France \\ alexandre.de-bernardinis@ifsttar.fr, emmanuel.frappe@ifsttar.fr \\ ${ }^{2}$ LGEP CNRS UMR 8507 / SPEE Labs, 11, rue Joliot Curie, Plateau du Moulon, FR- 91192 Gif sur Yvette, France \\ olivier.bethoux@1gep.supelec.fr
}

Keywords: Segmented PEM fuel cell, fault tolerant strategy, power conditioning, multi-port isolated converter, resonant isolated boost.

\begin{abstract}
To fulfill the transport applications, either for traction or on-board auxiliaries systems, a power generator based on fuel cell needs significant power. For this purpose, long fuel cell stacks either mono or multi-stack systems are already implemented as technological solutions. Long stacks may though be affected by spatial discrepancies (fluidics, temperature) causing possible failures. The latter often occur on localized stack sections. A corrective action has to be taken to quickly restore the fuel cell state-of-health. As an alternative to fluidic action, segmented electrical action is explored in this paper. First, an "All or Nothing" solution achieved with electrical by-pass circuits is analyzed: it proved simple to implement but restrictive to exploit. Consequently, a "gradual" action is proposed by using the power electronics converter associated to the fuel cell. Hence, the present work investigates the approach consisting in individually driving the electric power delivered by each segment of a long Polymer Electrolyte Membrane Fuel Cell stack. Each segment is controlled independently according to its state of health. To achieve this objective, the article provides an extended multi-criteria analysis of several power converter topologies. The converter topology has to be in agreement with transportation specifications: simple, compact, having a high efficiency and should be adapted to manage fuel cell degraded modes. Among several studied topologies, resonant isolated boost stands out as a candidate topology. The related multi-port architecture and algorithm structure are analyzed by numerical simulations, taking into account degraded modes and technology considerations.
\end{abstract}

\section{Introduction}

The $21^{\text {st }}$ century environmental context induces more and more severe constraints in many fields especially transport and building which are the major energy consumers. Indeed, 2006 aggregate primary energy demand in final-use sectors is 2181 Mtoe (Millions of tons oil equivalent), i.e. $27 \%$ for industry, 2227 Mtoe, i.e. $27 \%$ for transport, and 2937 Mtoe, i.e. $36 \%$ for residential, services and agriculture [1]. Tackling climate change and societal demand require big shifts in government policies and measures. The European Commission establishes increasingly stringent standards on rational utilization and conservation of energy. For instance, the European Union adopted the Energy Performance of Buildings Directive (EPBD) in 2002 and revised in 2010 for reinforcing efficiency standards [2]. In the same way, European emission standards, Euro 1 to Euro 6 define the acceptable limits for exhaust emissions of new vehicles [3]. These limits are shown in Figure 1.

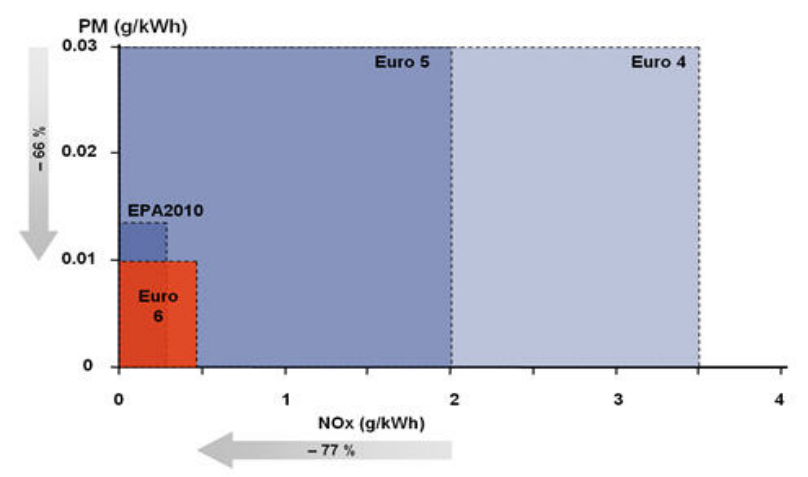

Fig. 1. Euro 6 standards.

Electric vehicles (EV) have long-term potential as future main-stream vehicles because of their high efficiency (regenerative braking) and low emission characteristics. Electrochemical batteries (Li-Ion based), or hydrogen (associated with fuel cells) can both supply the on-board 
primary energy of such vehicles. Fuel cell vehicles (FCV) are the most likely candidate for heavy duty or long distance applications, thanks to the high energy density of hydrogen ensuring an attractive autonomy. Among the available Fuel Cell (FC) technologies, the proton exchange membrane (PEM-FC) has several attractive features for automotive applications, such as low operating temperatures, relatively low cost and quick start up, simplicity, viability, and high efficiency [4-6].

Nevertheless, vehicles undergo many important constraints. They endure huge and frequent power variations (acceleration, braking, variable slope ...), a high thermal and humidity changes, permanent vibrations... These perturbations can affect the fuel cell performance in terms of efficiency, continuity of service and lifetime [7-9]. For example, the polymer electrolyte membrane (now operating below $100^{\circ} \mathrm{C}$ ) has to be fully water saturated in order to enhance its ionic conductivity. Flooding, due to an excess of water in the cells, inhibits gas transport to the reaction sites and reduces the active surface area of the catalysts, leading to a decrease of the cell efficiency [10-13]. On the contrary, a drying situation results in an increase of the membrane resistivity also reducing cell efficiency [14].

In a vehicle the FC power generator has to be reliable and with a high availability. In order to achieve this objective, it is essential to identify accurately and quickly the FC state of health $(\mathrm{SoH})$ and then to control FC behavior thanks to appropriate actuators.

In [15], authors propose fast fault detection identification (FDI) method based on space distribution discrepancies throughout the FC stack. This monitoring technique proved to be simple, reliable and non-intrusive. Hence it can be applied in mass market applications.

To maintain the FC closed to its optimal working point, many solutions have been proposed and tested [16-22]. The fluidic action based on fuel cell conditioning auxiliaries (air compressor, humidifier, temperature regulation) is already a solution. However, for long stacks, faults can appear on localized areas, mainly affecting some cells or groups of cells [15]. Then, the fluidic circuitry may become complex to be used in case of fault appearance.

In this present paper, electrical power conditioning is explored as a new corrective action. For this purpose, power converters can be considered either as a global electrical interface for the FC generator or can act on localized areas of the stack. Indeed, as fuel cell voltage significantly varies according to power, these converters are naturally present in a fuel cell system to regulate the load voltage. Considering the fact that faults will mainly affect some particular cells or groups of cells, a localized power converter architecture will be rather explored.

The paper is organized as follows: First (section 2), in case of fuel cell stack failure; the possible electric actions are presented. In particular a focus is done on the "All or Nothing" action. The third section describes electric action using the static power converter in order to gradually adjust the FC power. Hence, several converter topologies are evaluated according to technical specifications and their efficiencies calculated by numerical simulation. A candidate topology is retained. The forth section enlightens the global "multi-port" power converter architecture. DC bus voltage regulation, degraded working modes with fault tolerant strategy, and technology choices are presented. Section five draws conclusion and exposes some perspectives.

\section{Possible electric actions on the fuel cell in case of failure}

\section{1 “multi-stack" and segmented concepts for fuel cell}

The use of several fuel cells is an attractive industrial solution for power increase, since it is based on standardtechnology stacks with optimised size, low cost ancillaries and for which conditioning is easier. These generic modules are fully integrated with their fluidic and power conditioning [23-26]. The association of these generic modules builds a "multi-stack" fuel cell generator [27]. Figure 2 illustrates this concept. In addition, this idea can be expanded to a long and segmented fuel cell stack. This structure is relevant, because the fluidic circuitry is then common for the entire stack: fluidic management is simplified relatively to the multi-stack concept.

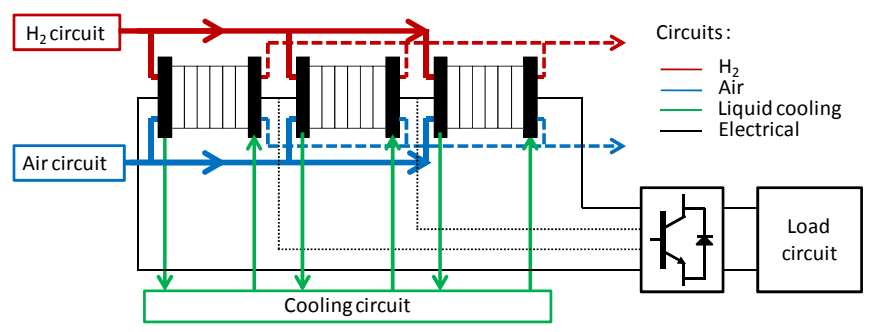

Fig. 2. The multi-stack concept for fuel cell.

The segmented concept for fuel cell, shown in Figure 3, may encounter some technical manufacturing constraints. Due to water accumulation in the stack during electrochemical reactions, the long stack assembly should be waterproofed, and mechanically stable with a sufficient and uniform tightening (clamping) torque. Clamping pressure on the endplates can impact on the MEA (Membrane Electrode Assembly) performance, and a trade-off should exist between mechanical pressure and mass transport of the species [2830]. Nowadays assemblies of hundreds of cells are technologically feasible for power fuel cells.

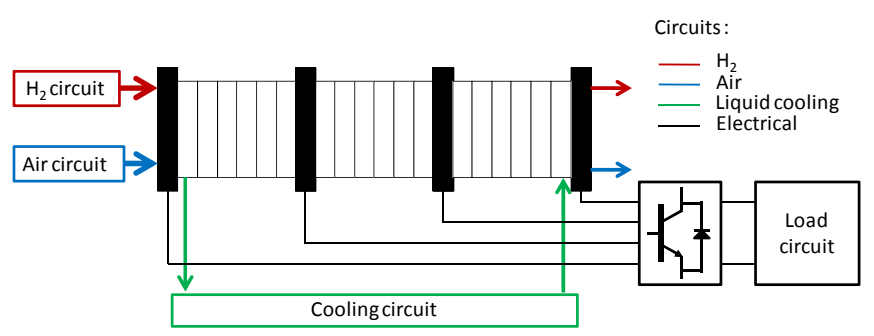

Fig. 3. Segmented fuel cell concept. 
To keep the stack in good health condition, Figure 2 shows that two kinds of actions are possible: the fluidic action (flow, pressure, temperature, humidity rate) and the electric action thanks to the power converter or use of dedicated switches. However, in this type of architecture, fluidic action may be limited. Indeed, its dynamic response is relatively slow; its implementation is rather complex and bulky.

Moreover, Figure 2 highlights that no specific action on a segment can be performed for a segmented fuel cell stack.

These comments on the two possible actions drive us to retain the electrical solution for the corrective action on the fuel cell under fault.

First a simple and economic way to operate on a fuel cell further to the appearance of a fault is to disconnect this last one. This action is called "All or Nothing" action.

\subsection{The "All or Nothing" action for "multi-stack" and segmented fuel cell stacks}

The principle of the by-pass was applied in industry in several applications which require the continuous availability of electric power. This solution has been already investigated in many patents and realizations. Strasser proposes an assembly of generative $8+1$ fuel cells for a military submarine [31]. In case of the appearance of a defect, the defective fuel cell is switched off. An anti-parallel diode ensures the current continuity. A healthy back-up fuel cell module, which can be operated at any moment, allows to compensate the loss of the failing fuel cell. Schulte [32] describes a "by-pass" system for a serial or parallel association of many fuel cell stacks. Ronne et al. apply for a patent [33] which describes a system to disconnect a failing fuel cell module of its electrical load.

Experiments of by-pass on a fuel cell stack are also presented in $[34,35]$ and were performed in FCLAB in Belfort, France. The electric set-up is presented in Figure 4. The by-pass circuit is composed of an anti-parallel diode (Diode AP) which allows the FC current continuity when the fuel cell under fault delivers no power. A second similar fuel cell module in series is emulated by a DC power supply. The electronic load imposes the load current amplitude. The experiments have simulated a break in the air gas flow supplying the cathode; it leads to a "starvation" phenomenon due to the lack of reactant feeding the fuel cell electrodes [3638]. The air gas flow is voluntarily stopped by imposing a zero reference on the compressor (acting as an air flow regulator) so that the air pressure at stack inlet falls down to zero (Figure 5). Simultaneously the load current continues to pass through the $\mathrm{FC}$ and the stack operates in abnormal condition with insufficient gas reactant supply. The FC voltage decreases consequently to values close to zero Volts (Figure 6) and when the Diode AP conduction threshold is reached, the Diode AP switches-on (Figure 7). Authors demonstrate that the diode in anti-parallel with the fuel cell stack may be not sufficient [35]; it enters in conduction only when the fuel cell voltage reaches the threshold of the antiparallel diode which is approximately $-0.7 \mathrm{~V}$. This value is critical and may be destructive for the fuel cell, because this latter works in electrolysis mode. An additional switch
(On/Off electric contactor) is placed in series with the tested fuel cell to ensure the proper electric disconnection of the stack. Another solution to enable the Diode AP conduction consists in adding a diode S2 in series with the stack; it forces the triggering of the Diode AP conduction by imposing a sufficient voltage drop. Such a solution is necessary when the failed FC stack has a global voltage too low to allow the antiparallel diode conduction.

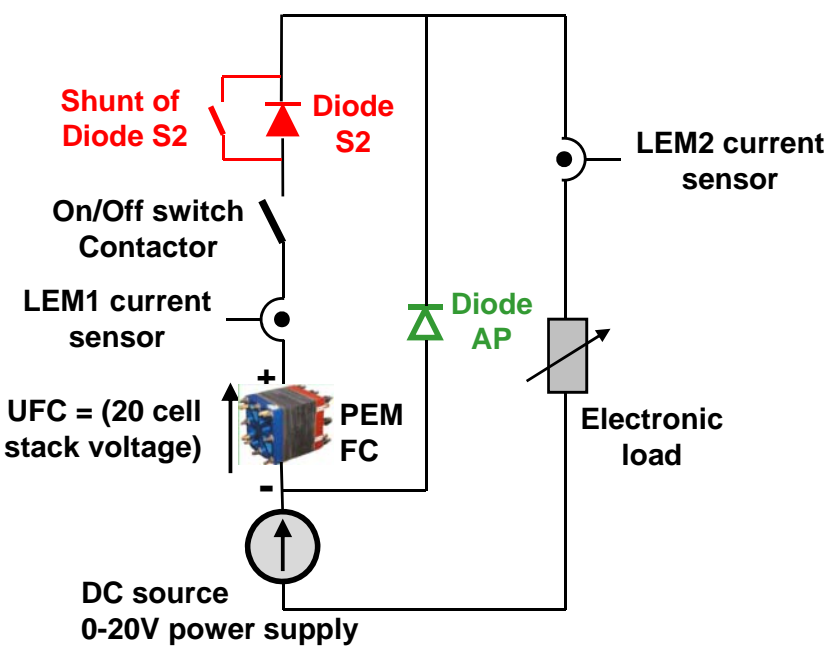

Fig. 4. Experimental set-up for PEM Fuel Cell by-pass.

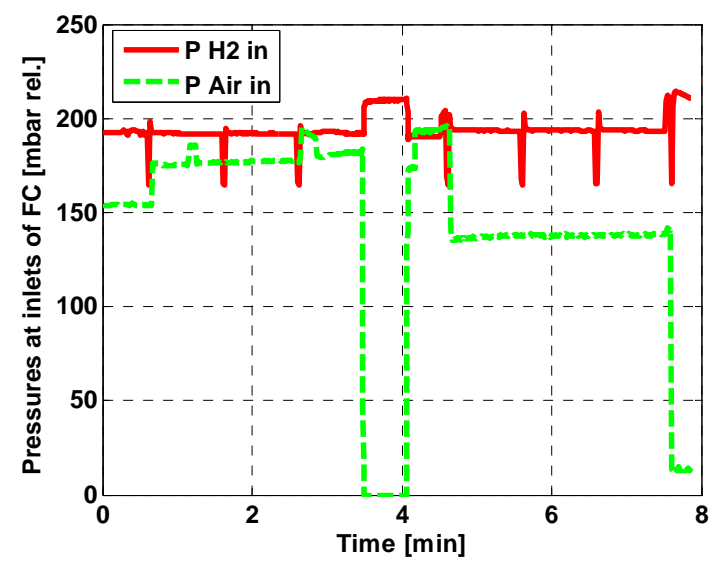

Fig. 5. Hydrogen and air rel. pressures at FC inlets.

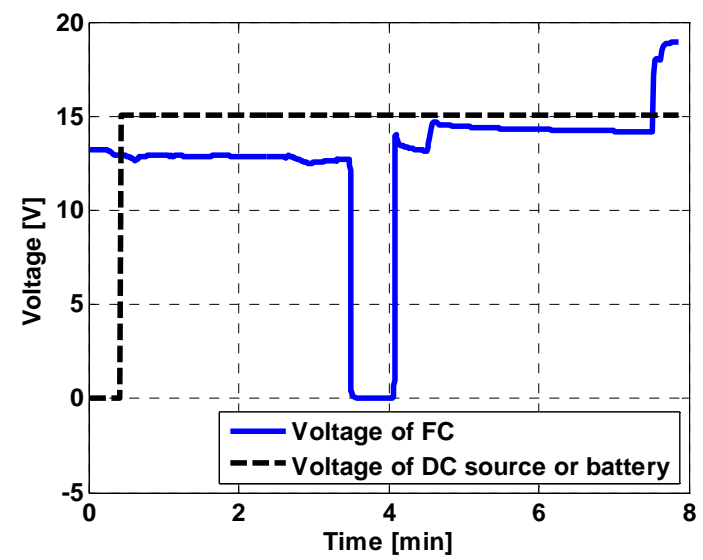

Fig. 6. Fuel cell and DC power supply voltages. 


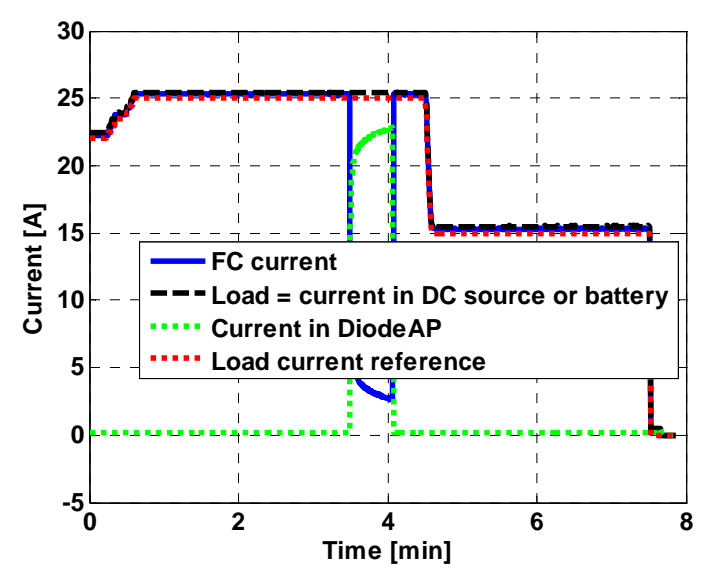

Fig. 7. Experimental validation of Diode AP conduction.

The by-pass action is also applied in heavy-duty ground transport requiring operation on degraded mode [39]. Two power fuel cells of $50 \mathrm{~kW}$ are connected in series; in case of a defect on a fuel cell this last one is disconnected. The system operates with a restricted power (half of rated power), ensuring limited propulsion of the vehicle and supply of the essential vehicle devices.

Figure 8 illustrates the by-pass principle for a 3 fuel cell modules multi-stack. The switches Ti permit to disconnect a faulty stack; anti-parallel diodes Di ensure the derivation of the current flow. Hence, in degraded modes, the FC generator can deliver either $2 / 3$ or $1 / 3$ of its nominal power. Subsequently this "All or Nothing" action leads to a significant power loss.

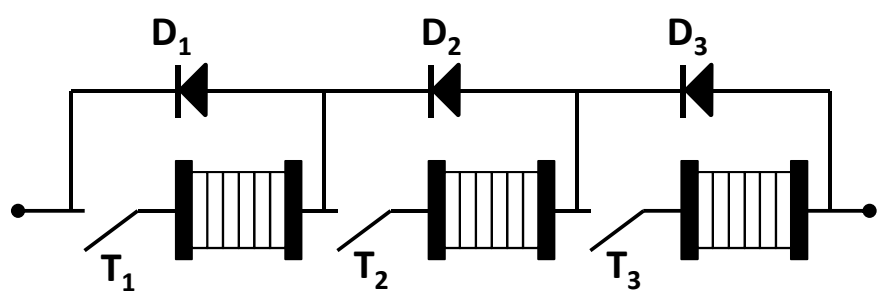

Fig. 8. By-pass concept with diodes for multi-stack fuel cells with series contactors.

As mentioned before, the segmented architecture is worth to be considered. That is the reason why our work intends to generalize the by-pass concept to this structure. Nevertheless, it induces some other constraints. Indeed it is not possible to insert switches in series between cells. Thus another solution has to be designed. Figure 9 illustrates the proposed strategy for a 3-segment PEM fuel cell. The circuit becomes more complex with added external diodes and switches $\left(T_{11}, T_{12}\right.$, $\mathrm{T}_{21}, \mathrm{~T}_{22}$ ). The fault management leads to a higher power loss. As a matter of fact, when the central segment is the unique under fault part, $\mathrm{T}_{12}$ or $\mathrm{T}_{22}$ have to be switched-off. Consequently, one of the external segments is disconnected, leading to a $2 / 3$ power loss. Namely, $T_{11}$ and $T_{12}$ opening stops the current in the center and top segments, $T_{21}$ and $T_{22}$ opening stops the current in the center and bottom segments.
Nonetheless, only a third of the power is lost when $T_{11}$ or $T_{21}$ are open to protect the top or the bottom segments respectively.

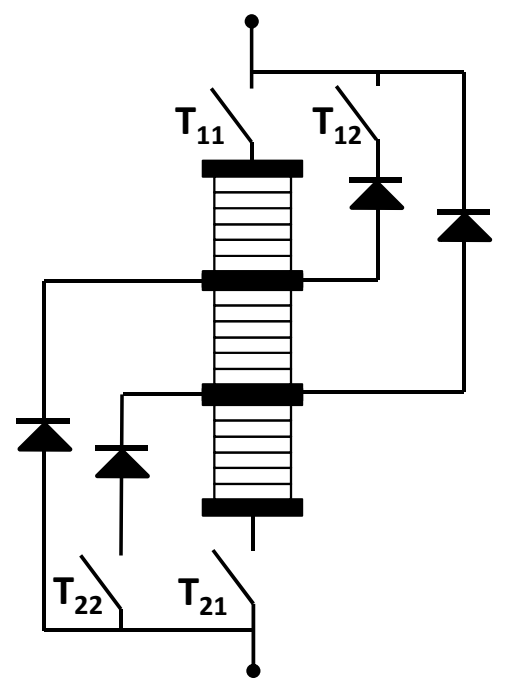

Fig. 9. Example of by-pass circuit for 3-part segmented PEMFC stack.

Such strategy can be generalized to a $n$-segment fuel cell stack. Figure 10 presents the suggested generic approach for an n-segment PEM fuel cell. It shows that, only opening T11 leads to by-pass of the current through T12 because any segment has a positive voltage. When T11 and T12 are switched-off, segments S1 and S2 are by-passed through T13. In order to by-pass a segment $\mathrm{Si}$, the algorithm chooses to open either T11 and T12 to T1i or T21 and T2(n-1) to T2(n-i) regarding the number of disconnected segments.

The by-pass of defective cells or segment also requires accuracy. Indeed the added current plugs for each segment should not disturb the current distribution by creating locally induced heating due to eddy current generation. The solution should consist in having low losses materials, and short isolated plugs. Moreover the by-pass circuit should not perturb the global current flow through the fuel cell stack. 


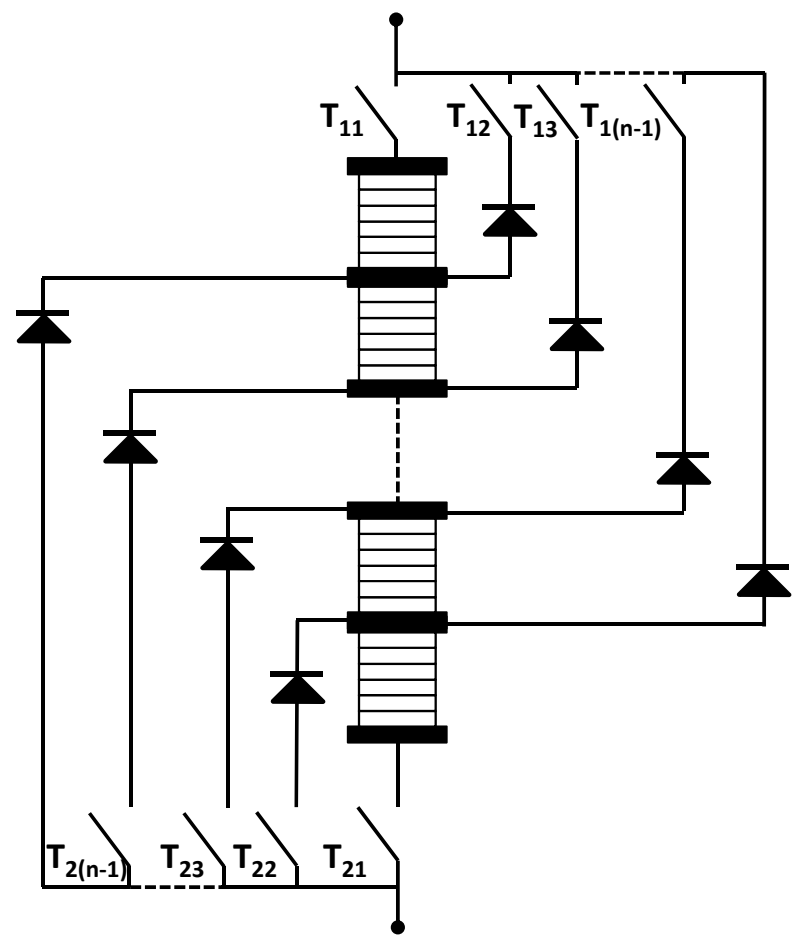

Fig. 10. Generic approach with by-pass circuit for n-segment PEM fuel cell stack.

The loss of a substantial part of the power further to the bypass action, and especially when the number of segments becomes important, leads to explore another solution for an electric corrective action: Namely static converters can adjust gradually the FC segment power.

\section{Electric action using the power converter interface}

Power converter should have high efficiency, and compactness regarding transportation constraints. They can be considered either as a global electrical interface for the FC generator or can act on localized areas of the stack.

Considering the fact that faults will mainly affect some particular cells or groups of cells, localized power converter architecture is preferably explored. In the case of a segmented fuel cell stack as depicted in Figure 3, an isolated structure is mandatory.

As both fuel and load are DC power sources, the power transfer requires an $\mathrm{AC}$ stage. The source interconnection can be realized either using an AC-link or a DC one. Both architectures are presented in Figures 11 and 12.

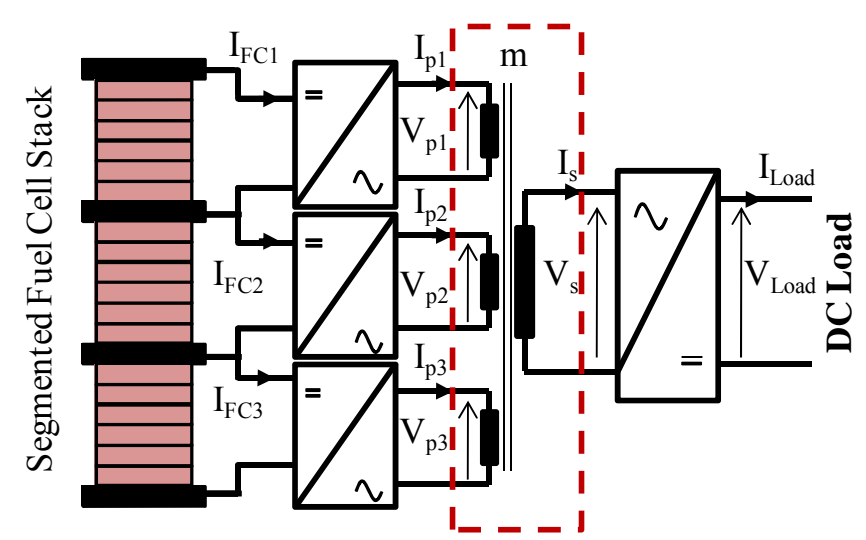

Fig. 11. Electrical architecture with AC-link (AC node).

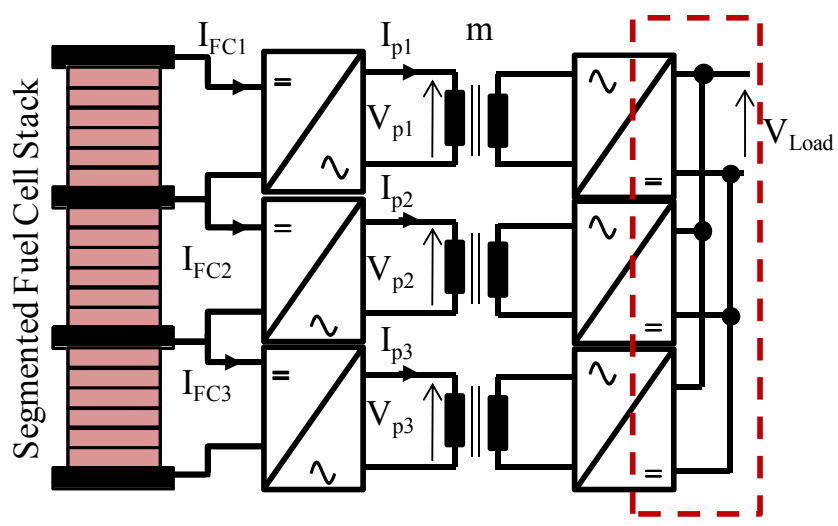

Fig. 12. Electrical architecture with DC-link (DC node).

These two approaches are compared on the basis of the following technical specifications:

The $30 \mathrm{~kW}$ fuel cell generator is subdivided into 3 parts of $10 \mathrm{~kW}, 200 \mathrm{~cm}^{2}$ of active area, 100 cells. The FC electrical characteristics are:

- No-load voltage: $100 \mathrm{~V}$

- Nominal current : 166 A

- Voltage at nominal load: 60V

The load voltage is regulated at $540 \mathrm{~V}$ DC using the converter. This voltage is a standardized value in railways and heavy road vehicles.

\subsection{Power transfer through the AC-link (or AC node)}

The FC segmented concept implies the use of isolation to supply the common load. A first approach is the AC-link. Some research works have already been published on the topic [40, 41]. The dual active bridge (DAB) structure proposed by De Doncker and Kheraluwala [42, 43] is composed of two similar inverters interconnected with a high frequency transformer. This concept is shown in Figure 13. The power transfer between two ports is achieved using a voltage phase shift and the leakage inductance $L_{k}$ (Figure 14). This topology features high power density and can be enlarged to multi-port topologies [44, 45]. Nonetheless, the power flow may become difficult to adjust as the number of ports increases $[46,47]$. 
To tackle this drawback, authors have proposed a control methodology enabling to decouple the energy fluxes. In order to achieve this properly, output AC voltage (Vs) and current (Is) are set in phase. In order to reduce switching losses, a zero voltage switching (ZVS) mode is also possible. This strategy has been detailed by authors in [48].

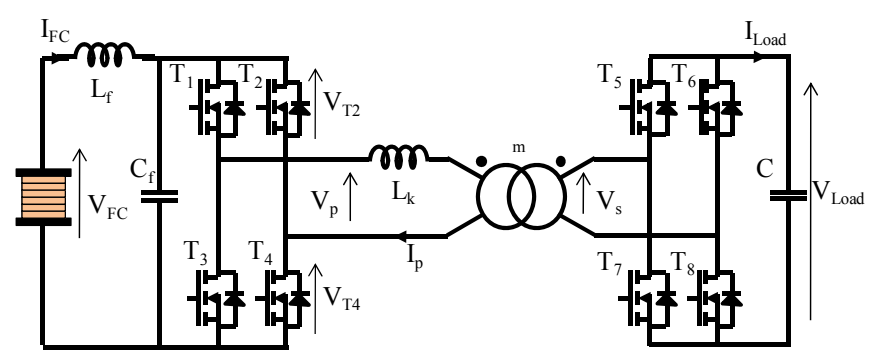

Fig. 13. Dual active bridge (DAB): Phase-shifted inverter.

(A)

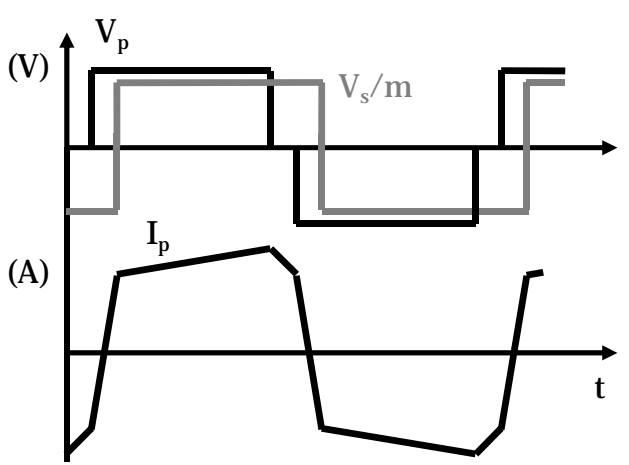

Fig. 14. Phase-shifted inverter topology: Typical waveforms.

However, the main drawback is that it cannot handle a wide input range, which is the case of a fuel cell [48]. Furthermore, because of the structure of voltage inverter, there is a presence of a strong AC current component which can have a negative impact on the fuel cell [49]. The use of an input filter is hence necessary, and consequently contribute to increase the global size of the converter. Thus, its use for this application is not recommended because of the FC electric characteristic. That is why another type of electrical coupling is studied.

\subsection{Power transfer through the DC-link (or DC node)}

In this second strategy, the power transfer is directly realized through the parallel connection of each converter DC output to the load (DC node) as shown in Figure 12. In this section, four different topologies are considered according to several criteria: efficiency, compactness, complexity, and impact on FC current ripple. The candidate topologies are respectively: double resonant inverter topology, half-bridge isolated boost, full-bridge isolated boost, and resonant isolated boost.

\subsubsection{Double resonant inverter topology}

This topology, based on a voltage inverter, a transformer and a double resonant circuit is presented in Figure 15. It has already been studied in several and varied domains like high voltage high power medical imagery application $[50,51]$ or $72 \mathrm{~V}$ lead-acid battery charger in shunting locomotive [52].
Its power is controlled through frequency tuning. This control value range (swing) is quiet small and bounded by the antiresonance frequency set by $\mathrm{L}_{\mathrm{p}}$ and $\mathrm{C}_{\mathrm{p}}$ adjustment (minimal frequency) and the series resonant frequency set by $\mathrm{L}_{\mathrm{S}}$ (in parallel to $\mathrm{L}_{\mathrm{p}}$ ) and $\mathrm{C}_{\mathrm{p}}$ adjustment (maximal frequency) (Figure 15). It is hence possible to limit the functioning of the converter between these two frequencies. The admittance transfer function $\mathrm{Y}(\mathrm{s})$ of $3^{\text {rd }}$ order for the resonant circuit is given by equation (1) in Laplace domain. It lets appear the two characteristic frequencies $\left(\mathrm{F}_{\min }\right.$ and $\left.\mathrm{F}_{\max }\right)$ computed as follows according to resonant parameters $\left(\mathrm{L}_{\mathrm{s}}, \mathrm{L}_{\mathrm{p}}, \mathrm{C}_{\mathrm{p}}\right)$ :

$$
\begin{gathered}
\bar{Y}(s)=\frac{\overline{I_{p}}(s)}{\overline{V_{p}}(s)}=\frac{1+\frac{s^{2}}{\omega_{\text {min }}^{2}}}{1+\frac{s^{2}}{\omega_{\text {max }}^{2}}} \times \frac{1}{\left(L_{s}+L_{p}\right) s} \\
F_{\text {min }}=\frac{1}{2 \pi \sqrt{L_{p} C_{p}}} ; \quad F_{\text {max }}=\frac{1}{2 \pi \sqrt{\frac{L_{s} L_{p}}{L_{p}+L_{s}} C_{p}}}
\end{gathered}
$$

The expression of the average output current $<\mathrm{I}_{\text {Load }}>$ according to input voltage $\mathrm{V}_{\mathrm{FC}}$, switching frequency $F$ and $m$ the transformer ratio, is as follows:

$$
\left\langle I_{\text {Load }}\right\rangle=\frac{4 V_{F C}}{m \pi} \cdot \sqrt{\frac{C_{p}}{L_{s}}} \cdot \frac{F}{F_{\max }}
$$

Equation (2) shows that the output current is independent from the output voltage. This converter behaves alike a current generator which value is proportional to the operating frequency $F$.

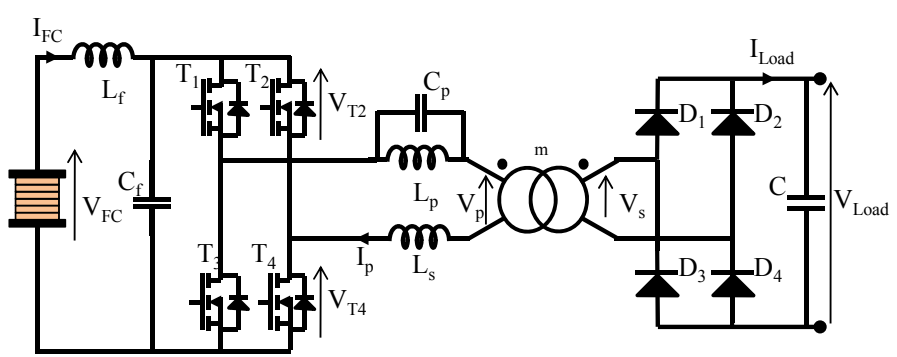

Fig. 15. Double resonant inverter topology.

This structure allows the power switches to commutate at zero current (ZCS) both for turning-on and turning-off (Figure 16). This zero current switching characteristic means switching losses cancellation. Consequently, the global converter efficiency is enhanced. 


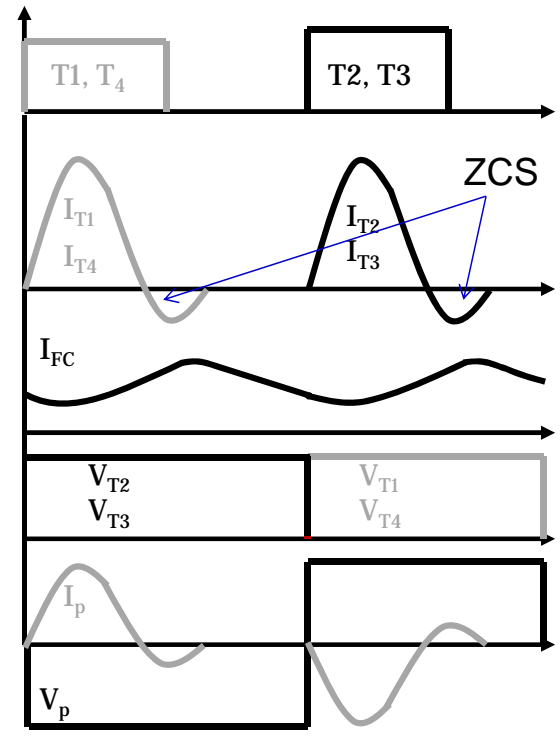

Fig. 16. Double resonant inverter: Typical waveforms.

Switches constraints (MOSFETs transistors $\mathrm{T}$ and output diodes $\mathrm{D}$ ) are calculated as follows, with $m$ the transformer ratio $m=10$, and $Z r$ the resonant impedance:

$V_{T \text { max }}=\frac{V_{\text {Load }}}{m}=50 \mathrm{~V}$

$I_{T \max }=I_{F C}+\frac{V c h}{m Z_{r}}=550 \mathrm{~A} ; \quad Z_{r}=\sqrt{\frac{L_{s}}{C_{p}}}$

$V_{D}=V_{\text {Load }}=540 \mathrm{~V}$

$I_{D \text { max }}=\frac{I_{T \text { max }}}{m}=50 \mathrm{~A}$

It makes this topology feasible, but this structure faces some drawbacks. Indeed, the transformer ratio is high $(m=10)$ mainly because of the low FC operating voltage. The switches rated currents are large and depend on resonant parameters. Moreover, this topology also requires an input filter to minimize the FC current ripple (Figure 15), which causes an increase of the global converter size.

Consequently in order to face the key problem of FC current ripple and to minimize the transformer ratio, boost converters topologies are preferred. Indeed, boost converter is composed of a reduced number of controlled switches, has high efficiency and permits to reduce the working constraints thanks to appropriate interleaving techniques. Furthermore a boost topology allows to directly controlling the FC current and its ripple. Boost converter topology is thus well adapted to the fuel cell electric features.

\subsubsection{Half bridge isolated boost}

The isolated boost is a structure derived from a 2-leg interleaved boost on which a galvanic insulation is added: a transformer is inserted between input transistors and rectifier output diodes (Figure 17) [53]. The switches (T1, T2) control values are identical and $\pi$ shifted. The converter voltage ratio
$\mathrm{V}_{\mathrm{Load}} / \mathrm{V}_{\mathrm{FC}}$ corresponds to a simple boost including the transformer ratio $m$ :

$$
V_{\text {Load }}=\frac{m}{1-\alpha} V_{F C}
$$

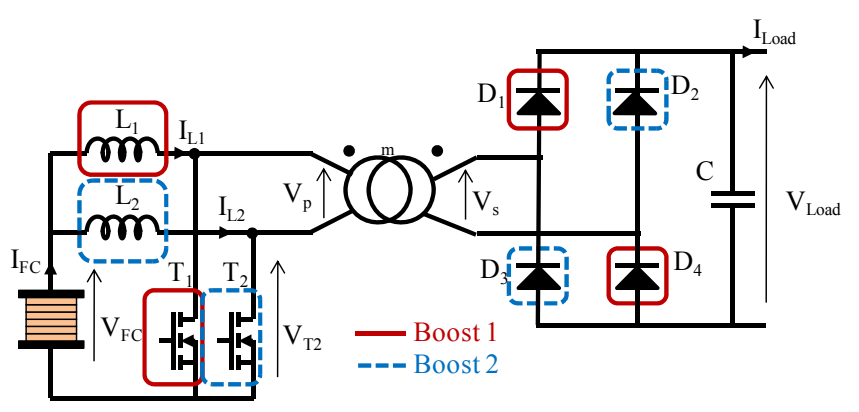

Fig. 17. Half-bridge isolated Boost.

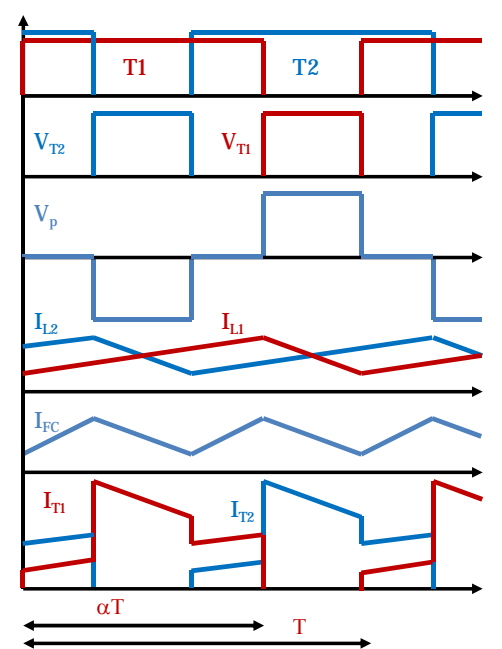

Fig. 18. Half-bridge isolated Boost: typical waveforms.

Electrical constraints on semiconductor switches, with a transformer ratio $m=2.5$, inductances values $\mathrm{L}_{1}=\mathrm{L}_{2}=165 \mu \mathrm{H}$ and a switching frequency $f=10 \mathrm{kHz}$ are:

$$
\begin{aligned}
& V_{T \text { max }}=\frac{V_{\text {Load }}}{m}=216 \mathrm{~V} \\
& I_{T_{\text {max }}}=I_{F C}+\frac{(2-\alpha) V_{s}(1-\alpha)}{2 m L_{1} f}=168 \mathrm{~A} \\
& V_{D}=V_{\text {Load }}=540 \mathrm{~V} \\
& I_{D \text { max }}=\frac{I_{F C}}{2 m}+(1-\alpha)^{2} \frac{V_{\text {Load }}}{2 m^{2} L_{1} f}=37 \mathrm{~A}
\end{aligned}
$$

Due to power electronics principles, the control values duty cycles $\alpha$ have to be higher than 0.5 (Figure 18). This implies that the converter cannot work in the complete fuel cell power range. Moreover this duty cycle condition leads to increase voltage constraints at the primary of the transformer. That is the reason why the full bridge isolated boost is considered; it allows transistor voltage reduction.

\subsubsection{Full bridge isolated boost}


A full-bridge isolated boost structure is proposed in [54] and Figure 19 shows its principle. The switches control values are identical to the previous half bridge topology and the voltage ratio $\mathrm{V}_{\mathrm{Load}} / \mathrm{V}_{\mathrm{FC}}$ is computed as follows:

$$
V_{\text {Load }}=\frac{m}{1-D} V_{F C}
$$

With $\mathrm{D}=2 \alpha-1$, the duty-cycle supported by the input inductance $\mathrm{L}$ and $\alpha$ the switches duty-cycle. Hence, although $\alpha$ has always to be kept higher than 0.5 , the boost operates with a duty cycle $\mathrm{D}$ ranging from 0 to 1 . As a consequence, the boost can work over all the FC power range.

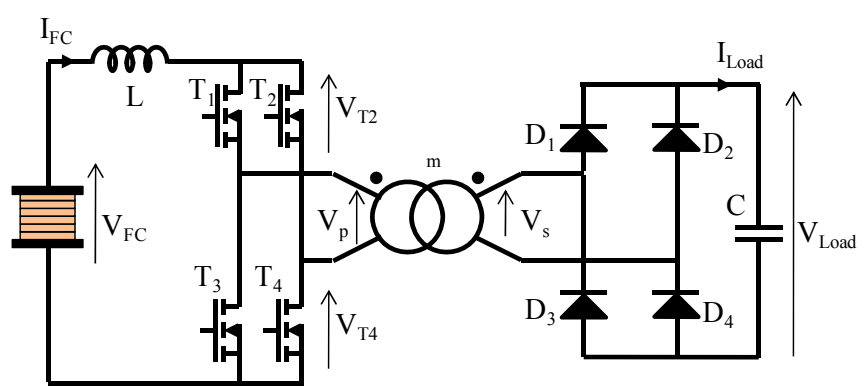

Fig. 19. Full-bridge isolated Boost.

The switches voltage constraints are divided by two. With a transformer ratio of $m=5$, an input inductance $\mathrm{L}=86 \mu \mathrm{H}$, the main constraints are as follows:

$V_{T \max }=\frac{V_{\text {Load }}}{m}=110 \mathrm{~V}$

$I_{T \max }=I_{F C}+\frac{(2 \alpha-1) V_{S}(1-\alpha)}{m L f}=180 \mathrm{~A}$

$V_{D}=V_{\text {Load }}=540 \mathrm{~V}$

$I_{D \max }=\frac{I_{F C}}{m}+(1-\alpha)^{2} \frac{2 V_{\text {Load }}}{m^{2} L f}=37 \mathrm{~A}$

It should be noted that both half and full bridge topologies operate in hard switching. Moreover, because of the transformer leakage inductance, they both require a clamping circuit operating during transistors switch-off. Such clamping circuit can be either active by adding a capacity and a switch [55] or passive by adding a diode, a capacity and a resistance [57]. Nevertheless, in both cases, the converter losses remains significant and the clamping circuit still dissipates power. Another option is to use the MOSFETs semiconductors in avalanche mode. In this case, the leakage energy is directly dissipated into the transistors and no additional passive element is required [56]. In order to use the MOSFETs in avalanche, it is necessary to make sure that the transformer leakage inductance $\mathrm{L}_{\mathrm{k}}$ is as small as possible and the transistor heat-sink is enough effective for this addition heat. Consequently, to make sure to minimize the converter losses, a third topology is introduced using transistor soft switching mode.

\subsubsection{Resonant isolated boost}

This resonant topology is suggested by several authors [57-59] and shown in Figure 20. A capacity $C_{p}$ is added to establish a quasi resonant circuit with the transformer leakage inductance $\mathrm{L}_{\mathrm{k}}$. The resonant circuit $\left(\mathrm{L}_{\mathrm{k}}, \mathrm{C}_{\mathrm{p}}\right)$ allows a zero current switching functioning (ZCS) illustrated in Figure 21. Consequently, this structure is not subject any more to the leakage energy over-voltage.

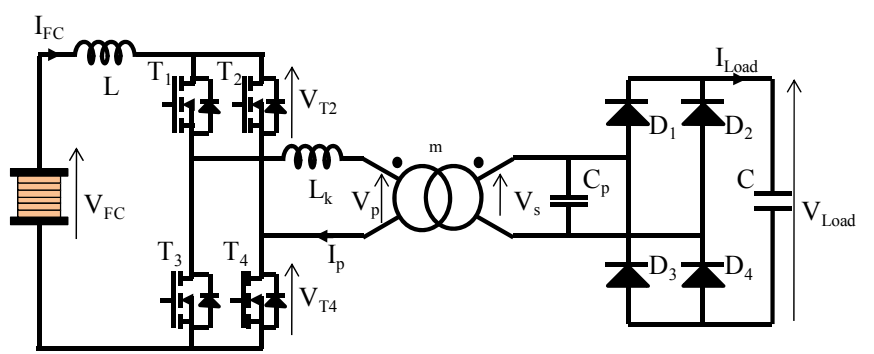

Fig. 20. Resonant isolated Boost topology.

The converter control is now held by frequency tuning. In steady states, the load voltage - FC voltage relation is given by:

$$
V_{\text {Load }}=\frac{m}{1-\frac{f}{f_{r}}} V_{F C}
$$

Equation (3) shows that the converter frequency control significantly evolves according to FC voltage swing. Namely, considering a fixed output voltage $\left(\mathrm{V}_{\mathrm{Load}}\right)$ and a $\left[\mathrm{V}_{\mathrm{FC}} / 2 ; \mathrm{V}_{\mathrm{FC}}\right]$ $\mathrm{FC}$ voltage range, the control frequency varies from $f_{\min }$ to $f_{\max }=2.5 f_{\min }$. Moreover, over the whole converter working range, the ZCS mode has to be validated.

The converter operating frequency is chosen between $17 \mathrm{kHz}$ and $38 \mathrm{kHz}$; $f_{\max }$ corresponds to the maximal current. These frequency values are a trade-off between acceptable losses for the semiconductors and size of the high frequency transformer. Resonant circuit parameters are $\mathrm{L}_{\mathrm{k}}=1.62 \mu \mathrm{H}$ and $\mathrm{C}_{\mathrm{p}}=2.61 \mu \mathrm{F}$. Selecting a transformer ratio $m=4$, an inductance $\mathrm{L}=38 \mu \mathrm{H}$, the switches constraints are computed as follows:

$$
\begin{aligned}
& V_{T \max }=\frac{V_{\text {Load }}}{m}=135 \mathrm{~V} \\
& I_{T \max }=\frac{V_{s}}{m \sqrt{\frac{L_{k}}{C_{p}}}}=170 \mathrm{~A}, \quad Z_{r}=\sqrt{\frac{L_{k}}{C_{p}}} \\
& V_{D}=V_{\text {Load }}=540 \mathrm{~V} \\
& I_{D \max }=\frac{I_{F C}}{m}=40 \mathrm{~A}
\end{aligned}
$$




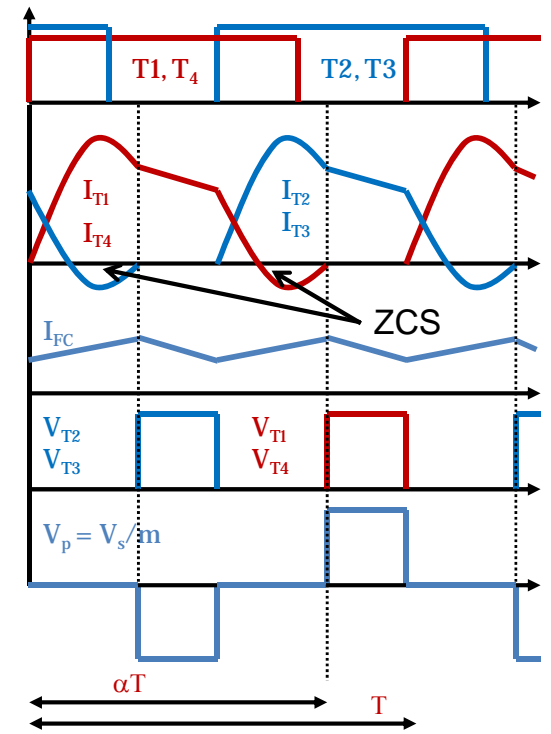

Fig. 21. Resonant isolated Boost: Typical waveforms.

\subsection{Efficiencies}

The five suggested electrical topologies have been simulated using the Matlab-Simulink ${ }^{\circledR}$ software. In a second step, global efficiencies have been evaluated using electrical parameters are based on the devices datasheet values. For this purpose, MOSFETs semiconductors losses (conduction and switching) are given as follows over a switching period:

$$
\begin{aligned}
& P_{\text {cond }}=R_{D S o n} \cdot I_{r m s}^{2} \\
& P_{s w}=\frac{f}{2}\left(V_{D S} I_{t o n} t_{o n}+V_{D S} I_{\text {toff }} t_{\text {off }}\right)
\end{aligned}
$$

Where $\mathrm{R}_{\mathrm{DS} \text { on }}$ is MOSFET on-resistance, $\mathrm{V}_{\mathrm{DS}}$ is the drainsource voltage.

Diodes conduction and switching losses are:

$$
\begin{aligned}
& P_{\text {cond }}=\left\langle V_{0} I_{d}\right\rangle+R_{d} I_{d r m s}^{2} \\
& P_{s w}=V_{D} Q_{r r} f
\end{aligned}
$$

$\mathrm{V}_{\mathrm{D}}$ is the diode conducting voltage; $\mathrm{Q}_{\mathrm{rr}}$ the reverse recovery charge, and $f$ the switching frequency.

At last, efficiency related to FC current performances are summarized in Figure 22 for the five studied converters.

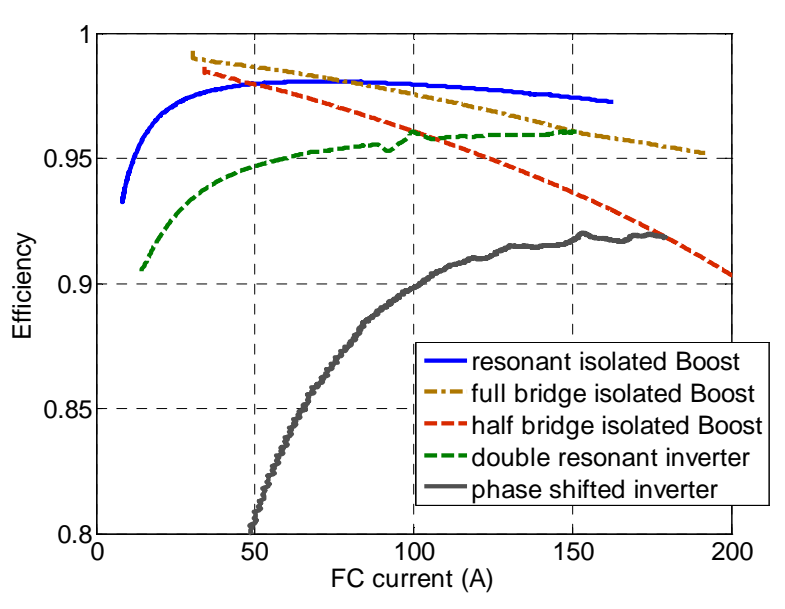

Fig. 22. Efficiency of studied power converters.

Full bridge isolated boost and resonant isolated boost present the best efficiency for current amplitudes above 80A. Nonetheless, the resonant isolated boost topology is preferred mainly because of the possibility to operate in ZCS, which means neither additional clamping circuit nor MOSFET overstress (due to avalanche mode). In the following section, numerical simulation results for the resonant isolated boost are presented.

\subsection{Simulation results for the resonant isolated boost}

The preferred $\mathrm{dc} / \mathrm{dc}$ converter topology for a multi-part segmented FC stack is the resonant isolated boost converter operated under a switching frequency control strategy. This subsection presents simulation results using MatlabSimulink ${ }^{\circledR}$ software.

Figure 23 shows the fuel cell power according to converter frequency. The rated power $(10 \mathrm{~kW})$ is achieved for the maximal frequency of $38 \mathrm{kHz}$.

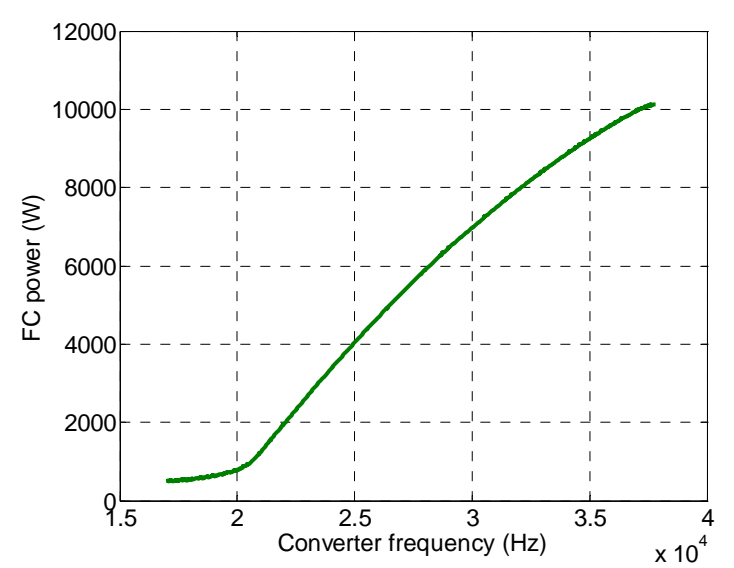

Fig. 23. FC power versus converter working frequency.

Figure 24 presents respectively load current transient from $20 \mathrm{~A}$ to $50 \mathrm{~A}$, DC bus voltage, FC current and FC voltage. The DC bus voltage regulation (explained in section 4) rejects the load disturbance and the overvoltage is minimized $(+/-5 \mathrm{~V})$. 


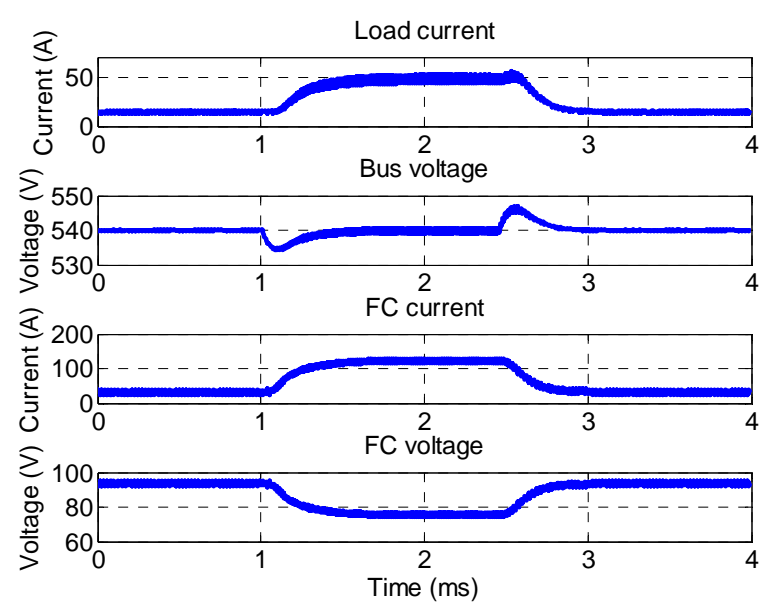

Fig. 24. Load variation and DC bus voltage regulation.

Following figures focus on the MOSFET T1 resonant current and FC current ripple for two different current amplitudes representing high (122A) and low (32A) FC power levels. The FC current ripple $\Delta \mathrm{I}_{\mathrm{FC}}$ can be computed as:

$$
\Delta I_{F C}=\left(\frac{m I_{F C} L_{k}}{V_{\text {Load }}}+\frac{1}{2 \pi f_{r}} \cdot\left(\pi-a \sin \left(\frac{m I_{F C} L_{k}}{V_{\text {Load }}}\right)\right)\right) \cdot \frac{V_{F C}}{L}
$$

where the resonant frequency $f_{\mathrm{r}}$ is: $f_{r}=\frac{1}{2 \pi \sqrt{L_{k} C_{p}}}$

with $\mathrm{L}_{\mathrm{k}}=1.62 \mu \mathrm{H}, \mathrm{C}_{\mathrm{p}}=2.61 \mu \mathrm{F}$, fr $=79 \mathrm{kHz}$, and $\mathrm{m}=4$ the transformer ratio. For a current ripple equal to $10 \%$ of $\mathrm{I}_{\max }$ (maximal current $=160 \mathrm{~A}$ ), the input inductance value is $\mathrm{L}=38 \mu \mathrm{H}$. Hence for $\mathrm{I}_{\mathrm{FC}}=122 \mathrm{~A}, \Delta \mathrm{I}_{\mathrm{FC}}=12.5 \mathrm{~A}$, and for $\mathrm{I}_{\mathrm{FC}}=32 \mathrm{~A}, \Delta \mathrm{I}_{\mathrm{FC}}=14 \mathrm{~A}$.

In both cases Figures 25 and 26 show that the FC current has an acceptable small ripple. Moreover, ZCS mode is achieved, which leads to a reduction of the dynamic losses.

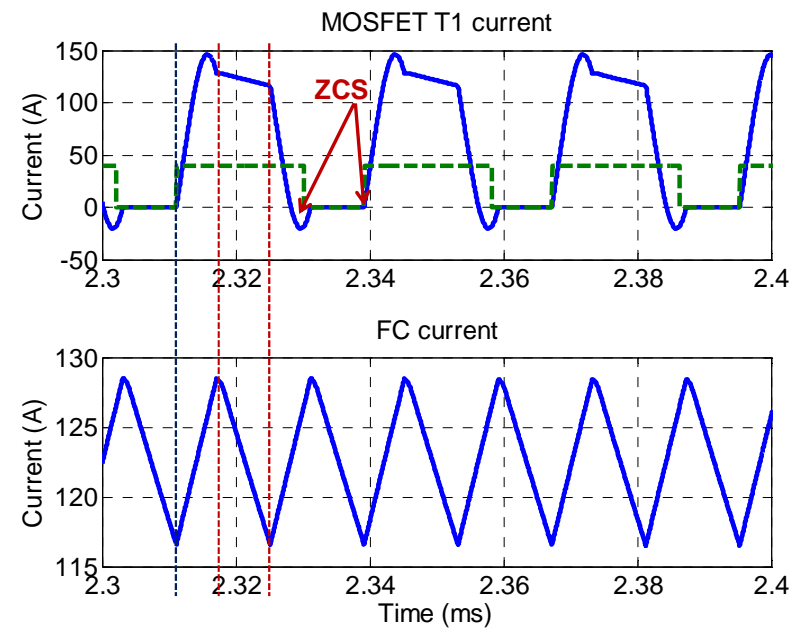

Fig. 25. MOSFET T1 current and FC current ripple for 122A.
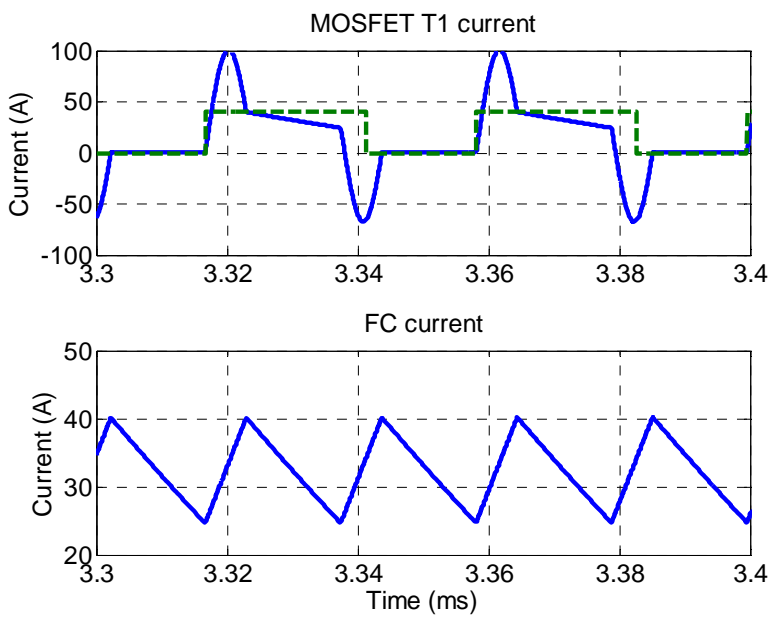

Fig. 26. MOSFET T1 current and FC current ripple for 32A.

\section{Multi-port converter system: DC bus voltage regulation - degraded modes and technology}

The objective of the multi-port converter system is to manage the power transfer from the 3-part segmented fuel cell to the DC load. It is designed to handle degraded working modes due to localized stack failure and occurring on a FC segment. First, this fourth section describes the DC bus voltage regulation; second it focuses on degraded mode examples and associated fault management strategy. It ends with technological aspects with the aim of implementation.

\subsection{DC bus voltage regulation}

Output voltage regulation of the 3-part segmented PEM fuel cell is performed using 2 cascaded loops and the principle shown in Figure 27. The outer loop is common to all the system and aims at regulating the bus voltage. The current reference $\mathrm{I}_{\mathrm{ref}}$ calculated by this regulation is sent to a current balancer (or dispatcher). This dispatcher distributes each converter current setpoint according to the global value Iref and the state of health of each segment. The three inner loops compare the current reference values with measured current values $\left(\mathrm{I}_{\mathrm{FC} 1}, \mathrm{I}_{\mathrm{FC} 2}, \mathrm{I}_{\mathrm{FC} 3}\right)$ and hence define each converter frequency control value $\left(f_{-}\right.$refl,$f_{-}$ref2,$f_{-}$ref3 $)$. as a result, in nominal conditions, each converter current reference is a third of the global reference given by the voltage loop. On the contrary, while a failure affects one FC segment, a current split strategy is implemented in order to relieve the $\mathrm{FC}$ segment under fault.

To be precise, the supervisor's role is to manage the current distribution (current split strategy) between FC parts according to the FC segments state of health. Moreover, in case of failure, and as a complement to the electric action, the supervisor has also the ability to modify the parameters of the fluidic auxiliaries. The load current may be also limited. Indeed, in case of sudden FC power decrease, it is mandatory to limit the DC load current in order to avoid a breakdown of 
the DC voltage. The multi-port system operates in degraded mode.

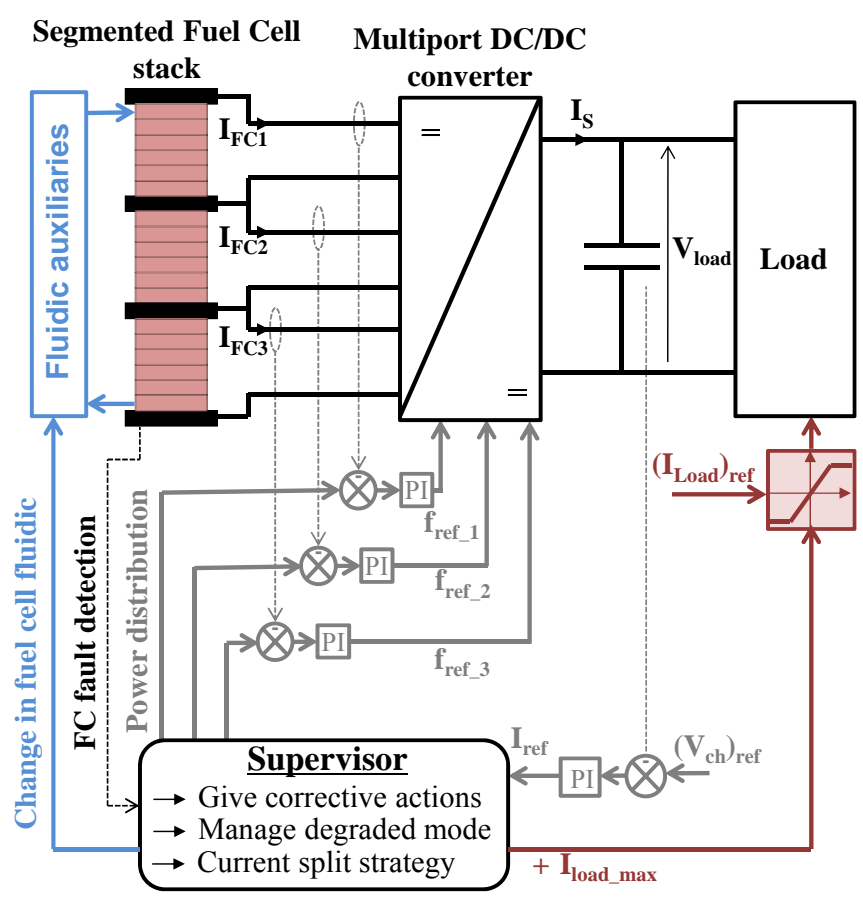

Fig. 27. Overall synoptic of the multi-port system regulation.

The following figures (Figures 28-a) and 29-b)) show the performance of the global multi-port system voltage regulation in case of successive load current steps. In this case the FC operates in normal and healthy mode. Successive load current steps vary from $15 \mathrm{~A}$ to $55 \mathrm{~A}$ (maximal tolerated load current), then down to 30A and 15A (Figure 28-a).

We can observe a coherent evolution of the currents and voltages due to the successive load transients. The DC bus voltage is correctly controlled, thanks to the regulator dynamic. A low overvoltage $(+/-5 \mathrm{~V})$ on the DC bus can be noticed which corresponds to $1 \%$ of the DC bus voltage rated value.
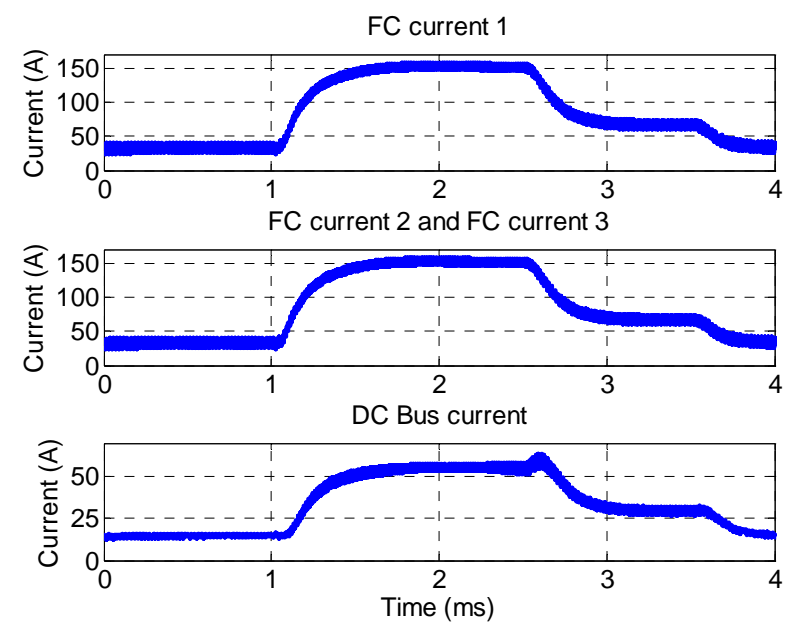

Fig. 28a. FC and load current during load variations.
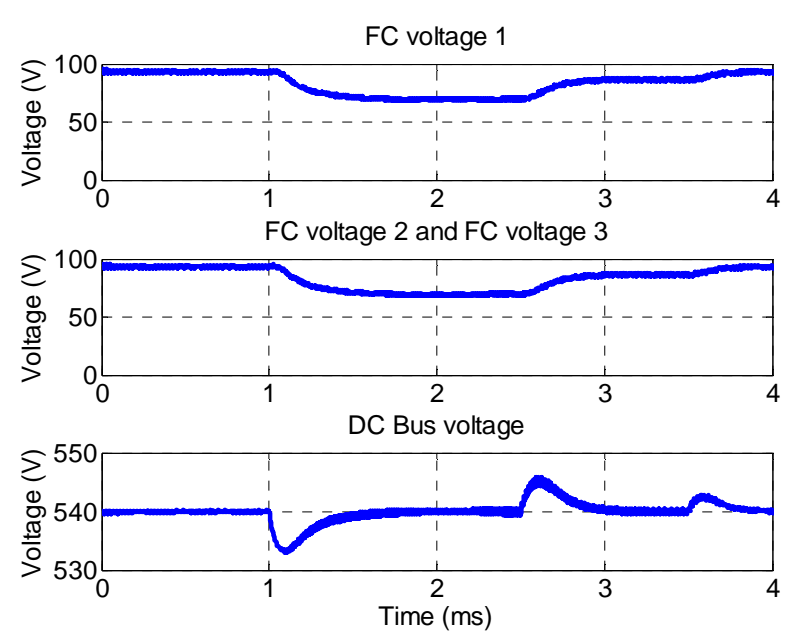

Fig. 28b. FC and DC bus voltage waveforms for load variations.

\subsection{Degraded working modes and current split strategy}

The sample hypothesis is that the FC stack is under fault (unhealthy state), and one segment is affected by the fault. Two different tests are performed using electric action rather than exploiting fluidic ancillaries control. The first one (noted Action 1) is a limited (moderated) power action on one FC segment (partial segment power removing). The second action (Action 2) deals with a loss of a FC segment due to current cancellation (complete segment power removing).

\subsubsection{Action 1: Partial action on the defective FC segment}

As a result of the appearance of a fault on FC segment FC1, a moderated current reduction of $1 / 3$ of $\mathrm{I}_{\mathrm{FC} 1}$ is applied. This current decrease is compensated by the two other healthy segments. The management strategy induces a current split of $2 / 3 ; 7 / 6 ; 7 / 6$ for the 3 FC segments. Naturally, in case of high current amplitudes, the power consumed by the load has to be limited in order to avoid a power mismatch between FC maximum power and load requested power. Namely, such a power disparity would lead to an important fall of the DC voltage bus when both healthy FC segments are saturated to their rated power. Figures 29-a) and 29-b) illustrate the effects of the current split strategy. Before fault detection, the load current reference was set to $48 \mathrm{~A}$. At $\mathrm{t}=2 \mathrm{~ms}$, FC1 segment is relieved from a third of its previous power. Consequently the load current is limited to $5 / 6$ of the maximal load current, which corresponds to $46.25 \mathrm{~A}$ for $\mathrm{I}_{\text {load_max }}=55.5$ A $\left(30 \mathrm{~kW}\right.$ under $\left.\mathrm{V}_{\text {load }}=540 \mathrm{~V}\right)$. 

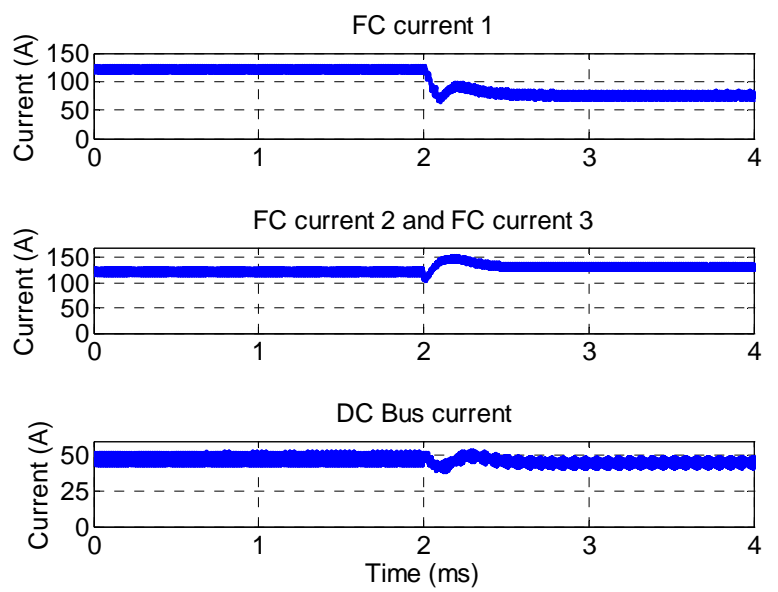

Fig. 29a. FC and DC load current waveforms for moderated power decrease affecting one FC segment.
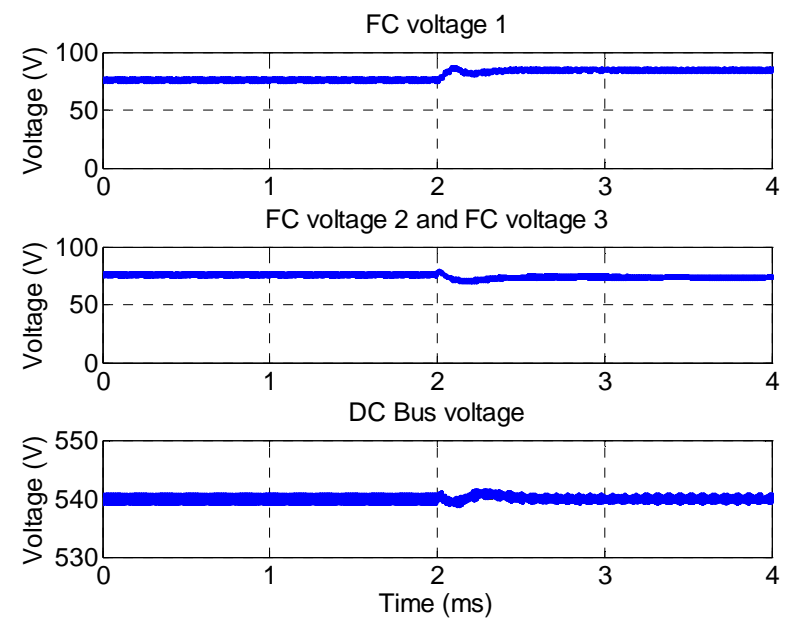

Fig. 29b. FC and DC load voltage response for moderated power decrease affecting one FC segment.

It can be noticed that during this action, the DC voltage bus remains controlled to its nominal value of $540 \mathrm{~V}$. Simultaneously, the current balancer makes more demand on both healthy segments (FC2 and FC3). For that reason their cell voltages should be preventively supervised during the degraded operation mode.

\subsubsection{Action 2: Loss of a FC segment due to current annulation}

In this second test, the first segment FC1 is considered under fault. This time health-saving measure is to bring down its current amplitude $\mathrm{I}_{\mathrm{FC} 1}$ to zero.

In that case, the whole transmitted power is reduced by a $1 / 3$ and no power offsetting is accomplished on the two healthy FC segments. The initial load current (48A) is hence limited to $2 / 3$ of its maximal amplitude (corresponding to $36 \mathrm{~A}$ ). Subsequently fuel cell segments FC2 and FC3 deliver their maximal current.

Figures 30-a) and 30-b) illustrate the effects of the loss of segment $\mathrm{FC} 1$. In this case, the $\mathrm{DC}$ voltage is correctly controlled with a dynamic response time in regulation lower than $1 \mathrm{~ms}$.

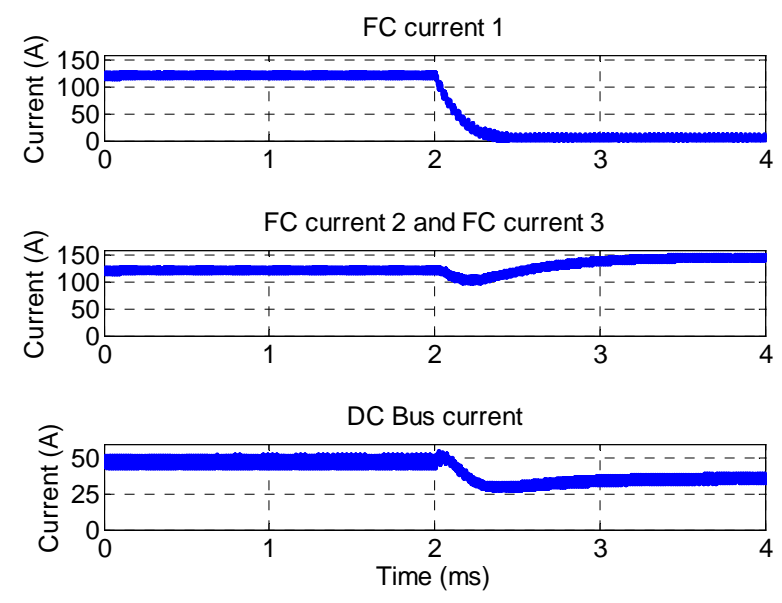

Fig. 30a. FC and DC load current waveforms for complete power decrease affecting one FC segment.
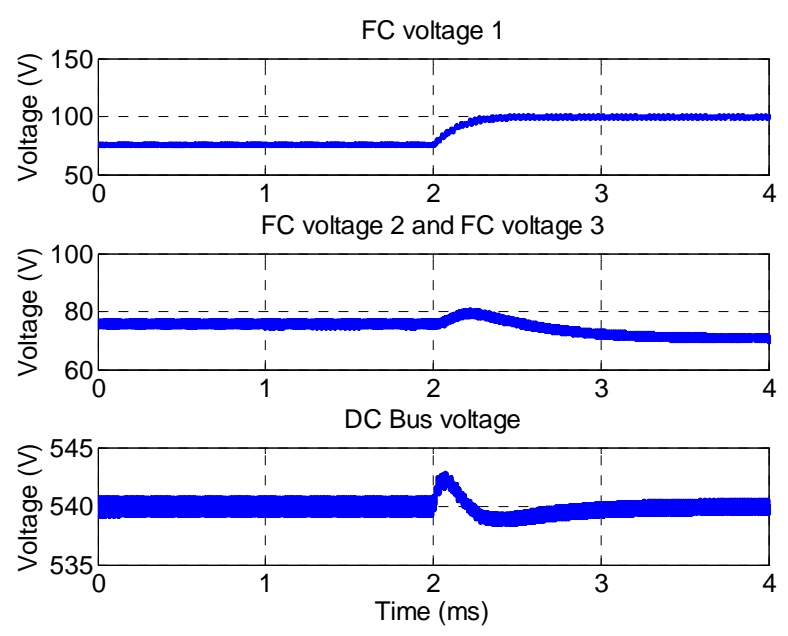

Fig. 30b. FC and DC load voltage response for complete power decrease affecting one FC segment.

Nevertheless, in such critical cases involving severe FC degraded modes, a fluidic action can complete the electric action: for instance, operating on air flow or cooling temperature would help to permit a FC power system continuity of service.

\subsection{Technological considerations}

High frequencies use (between 17 to $38 \mathrm{kHz}$ ) enables to use a transformer planar technology, which leads to a compact solution. The transformer is designed by Payton Company [60] with the desired characteristics: power $10 \mathrm{~kW}$, primary/secondary voltage $135 / 540 \mathrm{~V}$, primary/secondary current of $170 / 40 \mathrm{~A}$ and a leakage inductance equal to $1.6 \mu \mathrm{H}$. As the primary transformer voltage is low $(135 \mathrm{~V})$, and since high frequency range is aimed, MOSFETs technology is the best candidate for semiconductors. 
The chosen technology for the MOSFETs is the GigaMOS ${ }^{\mathrm{TM}}$ IXFN230N20T (200V/220A) from IXYS [61]. It features low on-state resistance $\left(\mathrm{Rdson}=7.5 \mathrm{~m} \Omega\right.$ at $\mathrm{Tj}=25^{\circ} \mathrm{C}$ ), fast intrinsic diode, isolation voltage up to $2500 \mathrm{VAC}$, and standard package in SOT-227 module.

Selected capacitances are medium power film capacitors from AVX, especially chosen for DC filtering. Finally, the input inductance design value is $38 \mu \mathrm{H}$ while its rated current is $160 \mathrm{~A}$. It has to stand a $10 \%$ current ripple. For inductance coil technology, ferrite or iron powder cores are favoured.

The chosen technology for the devices and passive components for the realization of the resonant isolated boost converter prototype are summarized in Table 1.

Table 1. Technology for resonant isolated boost.

\begin{tabular}{|c|c|c|}
\hline & $\begin{array}{c}\text { Constraints } \\
\text { (devices calibre) }\end{array}$ & $\begin{array}{c}\text { Technological } \\
\text { choice }\end{array}$ \\
\hline $\begin{array}{l}\text { Input } \\
\text { inductance : L }\end{array}$ & $\begin{array}{l}38 \mu \mathrm{H}, 160 \mathrm{~A}, \\
\Delta \mathrm{I}=10 \%(+/- \\
\left.16 \mathrm{~A}_{\max }\right)\end{array}$ & Iron powder cores \\
\hline $\begin{array}{l}\text { MOSFETs : } \\
\mathrm{T}_{1} \text { to } \mathrm{T}_{4}\end{array}$ & $135 \mathrm{~V}-170 \mathrm{~A}$ & $\begin{array}{l}\text { IXYS GigaMOS } \\
\text { IXFN230N20T } \\
\text { 200V-220A }[61]\end{array}$ \\
\hline $\begin{array}{l}\text { HF } \\
\text { Transformer }\end{array}$ & $\begin{array}{l}135-540 \mathrm{~V}, \\
170-40 \mathrm{~A} \\
\mathrm{~m}=4,10 \mathrm{~kW}\end{array}$ & $\begin{array}{l}\text { Planar technology } \\
\text { transformer from } \\
\text { "Payton planar } \\
\text { Magnetics" [60] }\end{array}$ \\
\hline $\begin{array}{l}\text { Resonant } \\
\text { capacitor : } \mathrm{C}_{\mathrm{p}}\end{array}$ & $\begin{array}{l}2.61 \mu \mathrm{F} \\
540 \mathrm{~V}-40 \mathrm{~A}_{\max }\end{array}$ & $\begin{array}{l}4 \text { capacitors in } \\
\text { series from TPC- } \\
\text { AVX } \\
\text { FFV } 36 C 0136 \mathrm{~K} \\
150 \mathrm{Vrms}-25 \mathrm{~A}_{\mathrm{rms}}\end{array}$ \\
\hline $\begin{array}{l}\text { Rectifier } \\
\text { diode bridge : } \\
\mathrm{D}_{1} \text { to } \mathrm{D}_{4}\end{array}$ & $540 \mathrm{~V}-40 \mathrm{~A}$ & $\begin{array}{l}\text { IXYS diodes } \\
\text { DSEP2x91-06A- } \\
600 \mathrm{~V}-90 \mathrm{~A}\end{array}$ \\
\hline $\begin{array}{l}\text { DC bus } \\
\text { capacitor : C }\end{array}$ & $\begin{array}{l}50 \mu \mathrm{F}, 540 \mathrm{~V}- \\
20 \mathrm{~A}\end{array}$ & $\begin{array}{l}\text { FFG86K0586K - } \\
600 \mathrm{~V}-44 \mathrm{~A}- \\
56 \mu \mathrm{F}\end{array}$ \\
\hline
\end{tabular}

\section{Conclusion and perspectives}

Power PEM fuel cell (FC) stacks used for vehicle propulsion or on-board auxiliaries can be either made of long and single stacks, or composed of multiple fuel cell modules, realizing a "multi-stack" association. The latter solution consists in industrial generic fuel cell stacks which are fully integrated and optimized in terms of fluidic and electrical conditioning. The first solution is also relevant since it minimizes any fluidic connections and hence enables to optimize the fuel cell system bulk. Indeed it is one of the main constraints of embedded systems. However long fuel cell stacks may be subject to disparities (fluidics, temperature) and, for this reason, can be impacted by some failures. Failures mainly occur on localized cells, affecting some specific areas of the stack (extremity, center...). Consequently this spatial discrepancy can be exploited through a differential method to enhance a fast and nonintrusive detection method [15]. Conversely, the present article investigates the dual approach consisting in individually driving the electric power delivered by each segment of a long stack. In summary, the segmented concept applied for long single stacks consists in splitting the stack into several parts (the segments), allowing to act on a defected area.

The possible actions can be divided into two categories. The first one, named the "All or Nothing Action" is simple and based on diodes and power contactors. The paper describes such architecture for an N-segment stack and explains the decision algorithm. The analysis brings to the conclusion that this "All or Nothing" process lead to a significant power loss in case of failure, in particular when the number of segments becomes important.

The second category, named the "Gradual Action" is more complex and based on power converters. Static converters are explored as a solution to adjust gradually the FC segment power. Indeed, as fuel cell voltage significantly varies according to power, static power converters are naturally present in a fuel cell system to regulate the DC load voltage. For this purpose, power converters can be considered either as a global electrical interface for the FC generator or can act on localized stack areas (regions). Considering the fact that faults will mainly affect some particular cells or groups of cells, localized power converter architecture has been investigated. Accordingly to the detection study presented in [15], the fuel cell generator is split in 3 parts. Each PEM fuel cell segment can be controlled independently according to its state of health $(\mathrm{SoH})$, through the static converter.

The segmented fuel cell requires galvanic isolation between segments and regarding the load. For this reason, only isolated converter structures are examined which naturally means an AC power stage. The AC-link possibility is eliminated for the reason that its behavior and efficiency are very sensitive to the fuel cell voltage variations and also because it creates an important fuel cell current ripple. These two features are certainly drawbacks for a FC application. Namely, FC current ripple may be a critical criterion regarding the ageing of the fuel cell, and its global performance [49].

The DC power node is hence a better solution: the power transfer is directly realized through the parallel connection of each converter output to the DC load. In this field, the different candidate converters (double resonant inverter topology, the half-bridge isolated boost, the full-bridge isolated boost, and the resonant isolated boost) are considered according to several criteria in connection with transportation specifications: power efficiency, compactness, "integrability", reliability, cost, fuel cell current ripple, tolerance to degraded working modes. Among the different converters, the resonant isolated boost seems the most appropriate solution. In particular, this converter permits continuous input current enabling small FC current ripple related to compact input filter. Additionally, it works in zero current switching (ZCS) mode, and so allowing high power efficiency. 
The above mentioned architecture has also been investigated in terms of power management. A complete load voltage regulation and dedicated control strategy is proposed and tested. Output voltage regulation is performed thanks to two regulation loops. The outer loop achieves the voltage regulation, and drives all the power system. The output value of this controller is a current reference. It gives the setpoints of each parallel inner loop controlling each converter current. This control structure permits to ensure the segment power balance either in nominal mode or failure case. In addition to the voltage regulation system, the supervisor's role is to manage power distribution between inputs according to the FC segments state of health.

The present article highlights that PEM fuel cell can be split into several segments both for failure detection and for relevant energy management aim. With this in prospect, the best power architecture is based on a DC-link and ZCS isolated boost converters. The FC health supervisor can act easily on the control scheme and hence drive the suitable power to each segment.

The principle of this work is to generalize this first approach to a hybridized fuel cell-battery (or Ultracapacitors) system. Indeed, in many transportation specifications, the battery has to assist the fuel cell in case of huge power transient and regenerative braking (sharp acceleration, deceleration and slope change). In this particular case, specific converter topologies should be defined together with energymanagement laws; the global system has to be developed and tested as well.

\section{References}

1. World Energy Outlook 2008, OECD/IEA, edited by IEA Publications, Paris, 2008.

2. Directive 2010/31/EU of the European Parliament and of the Council of 19 May 2010 on the Energy Performance Of Buildings (recast), Publication of the Official Journal of the European Union, 18.6.2010, L 153/13.

3. Regulation (EC) No $715 / 2007$ of the European Parliament and of the Council of 20 June 2007 on type approval of motor vehicles with respect to emissions from light passenger and commercial vehicles (Euro 5 and Euro 6) and on access to vehicle repair and maintenance information, Publication of the Official Journal of the European Union, 29.6.2007, L 171/1.

4. K. Sekizawa, N. Kitamura, K. Manabe, Y. Nonobe, M. Kizaki, and K. Kojima, ECS Trans. 33 (1), 1947 (2010).

5. P. Lin, P. Zhou, C. W. Wu, J. Power Sources, 194, 381 (2009).

6. P. Corbo, F. Migliardini, O. Veneri, Int. J. Hydrogen Energy, 32, 4340 (2007).

7. D. Candusso, F. Harel, A. De Bernardinis, X. Francois, M.-C. Péra, D. Hissel, P. Schott, G. Coquery, J.-M. Kauffmann, Int. J. Hydrogen Energy, 31, 1019 (2006).

8. A. De Bernardinis, F. Harel, L. Girardot, D. Candusso, D. Hissel, X. François, G. Coquery, S. Besse, Experimental Dynamic Performance of a $30 \mathrm{~kW}$ 90Cell PEFC Stack under Transportation Load Cycle Constraints, in EFCF 2009, Lucerne, Switzerland, 2009, pp. 1-16.

9. S. Knights, J. Power Sources, 127, 127 (2004).

10. N. Yousfi-Steiner, P. Moçotéguy, D. Candusso, D. Hissel, A. Hernandez, A. Aslanides, J. Power Sources, 183, 260 (2008).
11. H. Li, Y. Tang, Z. Wang, Z. Shi, S. Wu, D. Song, J. Zhang, K. Fatih, J. Zhang, H. Wang, Z. Liu, R. Abouatallah, A. Mazza, J. Power Sources, 178, 103 (2008).

12. Y. Park, J. Caton, J. Power Sources, 179, 584 (2008).

13. B. Wahdame, D. Candusso, F. Harel, X. François, M.-C. Péra, D. Hissel, J.-M. Kauffmann, J. Power Sources, 182, 429 (2008).

14. J. Ramousse, K.P. Adzakpa, Y. Dubé, K. Agbossou, M. Fournier, A. Poulin, M. Dostie, J. Fuel Cell Sci. Technol, 7, 041006 (2010).

15. E. Frappé, A. De Bernardinis, O. Bethoux, D. Candusso, F. Harel, C. Marchand, G. Coquery, Eur. Phys. J. Appl. Phys. 54, 23412 (2011).

16. J.P. Owejan, T.A. Trabold, D.L. Jacobson, D.R. Baker, D.S. Hussey, M. Arif, Int. J. Heat and Mass Transfer, 49, 4721 (2006).

17. N. Fouquet, C. Doulet, C. Nouillant, G. Dauphin-Tanguy, B. OuldBouamama, J. Power Sources, 159, 905 (2006).

18. G. Mulder, F. Deridder, P. Coenen, D. Weyen, A. Martens, Int. J. Hydrogen Energy, 33, 5728 (2008).

19. A. Hernandez, R. Outbib, D. Hissel, Journal Européen des Systèmes Automatisés, 42, 1225 (2008).

20. G. Fontes, C. Turpin, S. Astier, A large signal dynamic circuit model of a $\mathrm{H} 2 / \mathrm{O} 2$ PEM fuel cell: description, parameter identification and exploitation, in Proc. of FDFC 2008, Nancy, France, 2008.

21. J. Jang, H. Chiu, W. Yan, W. Sun, J. Power Sources, 180 (1), 476 (2008).

22. M. Hinaje, I. Sadli, J.-P. Martin, P. Thounthong, S. Raël, B. Davat, Int. J. Hydrogen Energy, 34, 2718 (2009).

23. J.-P. Poirot-Crouvezier, F. Roy, GENEPAC Project: Realization of a fuel cell stack prototype dedicated to the automotive application, in WHEC, Lyon, France, 2006, pp. 1-5.

24. N. Guillet, S. Didierjean, A. Chenu, C. Bonnet, P. Carré, B. Wahdame, L. Dumercy, X. François, L. Girardot, F. Harel, D. Hissel, S. Besse, S. Boblet, V. Chaudron, A. De Bernardinis, G. Coquery, S. Escribano, N. Bardi, Scientific and Technological Progress Toward the Development of an $80 \mathrm{kWe}$ PEM Fuel Cell System for Transport Applications, in EVS'07 23rd Electrical Vehicles Symposium, Anaheim, California USA, 2007.

25. C. Bonnet, S. Didierjean, N. Guillet, S. Besse, T. Colinart, P. Carré, J. Power Sources, 182, 441 (2008).

26. M. Miller, A. Bazylak, J. Power Sources, 196, 601 (2011).

27. A. De Bernardinis, M.-C. Péra, J. Garnier, D. Hissel, G. Coquery, J.-M. Kauffmann, Energy Convers. Manage, 49, 2367 (2008).

28. Woo-kum Lee, Chien-Hsien Ho, J.W. Van Zee, Mahesh Murthy, J. Power Sources, 84, 45 (1999).

29. J.J. Hwang, W.R. Chang, F.B. Weng, A. Su, C.K. Chen, Int. J. Hydrogen Energy, 33, 3801 (2008).

30. R. Montanini, G. Squadrito, G. Giacoppo, Experimental evaluation of the clamping pressure distribution in a PEM fuel cell using matrix-based piezoresistive thin-film sensors, in XIX IMEKO World Congress Fundamental and Applied Metrology, Lisbon, 2009.

31. K. Strasser, H2/O2-PEM-fuel cell module for an air independent propulsion system in a submarine, Handbook of fuel cells, edited by John Wiley \& Sons (2003), Pages: 1202-14.

32. J. Schulte, System and method for bypassing failed stacks in a multiple stack fuel cell. US Patent App. 20060127710, Published on June 15, 2006.

33. J. Ronne, R. C. Mihai, M. Shi, Fault management in a fuel cell-based system. US Patent App. 7862947B2, Published on 4 Jan 2011.

34. D. Candusso, A. De Bernardinis, M.-C. Péra, F. Harel, X. François, D. Hissel, G. Coquery, J.-M. Kauffmann, Energy Convers. Manage. 49, 880 (2008).

35. A. De Bernardinis, D. Candusso, F. Harel, X. François, G. Coquery, Energy Convers. Manage. 51 (5), 1044 (2010).

36. A. Taniguchi, T. Akita, K. Yasuda, Y. Miyazaki, J. Power Sources, 130, 42 (2004).

37. A. Taniguchi, T. Akita, K. Yasuda, Y. Miyazaki, Int. J. Hydrogen Energy, 33, 2323 (2008). 
38. M. Gerard, J.-P. Poirot-Crouvezier, D. Hissel, M.-C. Péra, Int. J. Hydrogen Energy, 35, 12295 (2010).

39. A. De Bernardinis, D. Candusso, F. Harel, G. Coquery, Power Electronics Interface for an Hybrid PEMFC Generating System with Fault Management Strategies for Transportation, in Proc. EPE 2009 Barcelona, Spain, 2009.

40. H. Tao, A. Kotsopoulos, J. L. Duarte, M. A. M. Hendrix, IEEE Trans Power Electron. 23 (2), 771 (2008).

41. L. Wang, E. G. Collins, H. Li, IEEE Trans. Veh. Technol., 60 (4), 1419 (2011).

42. R.W.A.A. De Doncker, D. M. Divan, M. H. Kheraluwala, IEEE Trans. Ind. Appl., 27, 63 (1991).

43. M. H. Kheraluwala, R. W. Gascoigne, D. M. Divan, E. D. Baumann, IEEE Trans. Ind. Appl., 28, 1294 (1992).

44. H. Bai, C. Mi, IEEE Trans. Power Electron., 23 (6), 2905 (2008).

45. F. Krismer, S. Round, J. W. Kolar, Performance optimization of a high current dual active bridge with a wide operating voltage range, in Proc. Power Electronics Specialists Conference, PESC'06, 2006.

46. S. Mariethoz, A. Rufer, Multisource DC-DC converter for the supply of hybrid multilevel converter, Conference Record of the 2006 IEEE Industry Applications Conference Forty-First IAS Annual Meeting, vol. 2, pp. 982-987, Oct. 2006

47. C. Zhao, S. D. Round, J. W. Kolar, IEEE Trans. Power Electronics, 23 (5), 2443 (2008).

48. E. Frappé, A. De Bernardinis, O. Bethoux, C. Marchand, G. Coquery, A Soft-Switching Multisource DC-DC Converter for Segmented PEM Fuel Cell Power Management in Vehicle Application, in IEEE Vehicle Power and Propulsion Conference, Chicago, 2011.

49. O. Rallieres, J. Mulot, D. Hissel, C. Turpin, F. Harel, M.-C. Péra, G. Fontes, S. Astier, Impact des ondulations de courant générées par un convertisseur DC-DC boost sur une pile à combustible PEM, in Proc. of Electrotechnique du Futur 2011, Belfort, France, 2011 (in French).

50. V. Croulard, G.-W. Baptiste, A. Durville, Double resonance electronic converter, US Patent Application Publication, US 2003/0231514A1, Publication date: 18 December 2003.

51. M. Zainea, E. Godoy, H. Cormerais, J. Buisson, H. Guéguen, A double resonance generator simulation using a hybrid approach, in Proc. EPE 2005 Conference, Dresden, Germany, 2005.

52. A. De Bernardinis, S. Butterbach, R. Lallemand, A. Jeunesse, G. Coquery, and P. Aubin, Double resonant converter topology with fast switching semiconductors for lead-acid battery charger used in hybrid electric locomotive, in IEEE International Symposium on Industrial Electronics, Gdańsk, Poland, 2011, pp. 239-244.

53. Y. Lembeye, V. D. Bang, G. Lefevre, J.-P. Ferrieux, IEEE Trans. Energy Conversion, 24 (1), 203 (2009).

54. M. Nymand, M. A. E. Andersen, IEEE Trans. Industrial Electronics, 57 (2), 505 (2010).

55. A. Vazquez, C. Aguilar, F. Canales, M. Ponce, Integrated power conditioner topology for fuel cell based power supply systems, in Proc. of IEEE PESC'08, 2008, pp. 223-229.

56. K. Wang, C. Y. Lin, L. Zhu, D. Qu, F. C. Lee, J. S. Lai, Bi-directional DC to DC converters for fuel cell systems, in Power Electronics in Transportation, Dearborn, USA, 1998, pp. 47-51.

57. H. Benqassmi, J.-P. Ferrieux, J. Barbaroux, Current-source resonant converter in power factor correction, in Proc. PESC'97. IEEE Power Electronics Specialists Conference, 1997, pp. 378-384.

58. J.-F. Chen, R.-Y. Chen, T.-J. Liang, Power Electronics IEEE Transactions on, 23, (1), 379 (2008).

59. R.-Y. Chen, T.-J Liang, J.-F. Chen, R.-L. Lin, K.-C. Tseng, Industry Applications, IEEE Transactions on, 44 (4), 1218 (2008).

60. P. Špánik, I. Feňo, G. Kácsor, I. Lokšeninec, Using planar transformers in soft-switchng DC-DC power converters, Application Note, Advances in Electrical and Electronic Engineering. Consulted online 10 Feb. 2012 at: http://www.paytongroup.com/info/Planar\%20trans._paper.pdf

61. Tech. Datasheet IXFN230N20T, IXYS Corp., DS100134A (06/11). 